\title{
Crustal thickness and images of the lithospheric discontinuities in the Gibraltar arc and surrounding areas
}

\author{
Flor de Lis Mancilla, ${ }^{1,2}$ Daniel Stich,,${ }^{1,2}$ José Morales, ${ }^{1,2}$ Rosa Martín, ${ }^{1}$ Jordi Diaz, ${ }^{3}$ \\ Antonio Pazos, ${ }^{4}$ Diego Córdoba, ${ }^{5}$ Javier A. Pulgar, ${ }^{6}$ Pedro Ibarra, ${ }^{7}$ Mimoun Harnafi ${ }^{8}$ \\ and Francisco Gonzalez-Lodeiro ${ }^{9}$
}

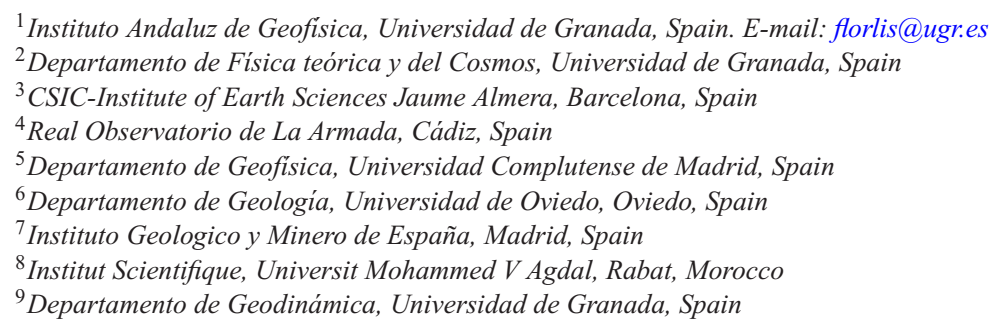

\section{SUMMAR Y}

The Gibraltar arc and surrounding areas are a complex tectonic region and its tectonic evolution since Miocene is still under debate. Knowledge of its lithospheric structure will help to understand the mechanisms that produced extension and westward motion of the Alboran domain, simultaneously with NW-SE compression driven by Africa-Europe plates convergence. We perform a $P$-wave receiver function analysis in which we analyse new data recorded at 83 permanent and temporary seismic broad-band stations located in the South of the Iberian peninsula. These data are stacked and combined with data from a previous study in northern Morocco to build maps of thickness and average $v_{P} / v_{S}$ ratio for the crust, and cross-sections to image the lithospheric discontinuities beneath the Gibraltar arc, the Betic and Rif Ranges and their Iberian and Moroccan forelands. Crustal thickness values show strong lateral variations in the southern Iberia peninsula, ranging from $\sim 19$ to $\sim 46 \mathrm{~km}$. The Variscan foreland is characterized by a relatively flat Moho at $\sim 31 \mathrm{~km}$ depth, and an average $v_{P} / v_{S}$ ratio of $\sim 1.72$, similar to other Variscan terranes, which may indicate that part of the lower crustal orogenic root was lost. The thickest crust is found at the contact between the Alboran domain and the External Zones of the Betic Range, while crustal thinning is observed southeastern Iberia (down to $19 \mathrm{~km}$ ) and in the Guadalquivir basin where the thinning at the Iberian paleomargin could be still preserved. In the cross-sections, we see a strong change between the eastern Betics, where the Iberian crust underthrusts and couples to the Alboran crust, and the western Betics, where the underthrusting Iberian crust becomes partially delaminated and enters into the mantle. The structures largely mirror those on the Moroccan side where a similar detachment was observed in northern Morocco. We attribute a relatively shallow strong negativepolarity discontinuity to the lithosphere-asthenosphere boundary. This means relatively thin lithosphere ranging from $\sim 50 \mathrm{~km}$ thickness in southeastern Iberia and northeastern Morocco to $\sim 90-100 \mathrm{~km}$ beneath the western Betics and the Rif, with abrupt changes of $\sim 30 \mathrm{~km}$ under the central Betics and northern Morocco. Our observations support a geodynamic scenario where in western Betics oceanic subduction has developed into ongoing continental subduction/delamination while in eastern Betics this process is inactive.

Key words: Subduction zone processes; Continental margins: convergent; Neotectonics; Crustal structure. 


\section{INTRODUCTION}

In the western Mediterranean region, the Gibraltar arc and the surrounding areas (the Betic and Rif mountain ranges) are the result of a complex tectonic evolution. The last tectonic event of relevance took place in the Neogene. At that time within a general plate convergence setting between the Eurasia and Africa plates, thrusting on the front of the orogene occurred simultaneously with extension in the Alboran domain (Internal zones of the Betic-Rif Orogen, Fig. 1; Lonergan \& White 1997).

There are still many uncertainties regarding what causes the westward motion of the Alboran domain and its overthrust above the Iberia and northwestern Africa paleomargins and the onset of the Alboran extension. Several theories have been put forward: delamination of subducted continental mantle lithosphere (e.g. Seber et al. 1996; Calvert et al. 2000; Duggen et al. 2004), an active continental subduction (e.g. Morales et al. 1999) and/or active oceanic subduction (e.g. Gutscher et al. 2002); processes related to the evolution of the western Mediterranean subduction system, such as retreat and tearing of the subducted oceanic slab (e.g. Lonergan \& White 1997; Duggen et al. 2004; Faccenna et al. 2004); a continental scale thermal mantle source (e.g. Hoernle et al. 1995); and convective removal or gravitational collapse of thickened continental lithosphere (e.g. Platt \& Visser 1989);

To resolve the puzzle of the tectonic evolution of this interesting region, we need more precise information about the present structure of the crust and lithospheric mantle. This was one of the motivations of the TopoIberia project (http://iberarray.ictja.csic.es/), a large-scale multidisciplinary research initiative to investigate the Earth's structure and dynamics in Iberia and northern Morocco. In this work we analyse data from the Topolberia consortion network together with data from a temporary experiment (INDALO). The used station distribution provides an unprecedented dense grid of $\sim 60 \times 60 \mathrm{~km}$ (Fig. 1).

We use these data for a $P$-wave receiver function analysis to obtain crustal thickness values and better images of the crustal and the lithospheric mantle structures. The receiver function technique is a well-established seismological technique that permits extraction of information about the lithospheric structure from the analysis of converted seismic waves at seismic discontinuities (e.g. Vinnik 1977; Langston 1979; Ammon 1991; Zhu \& Kanamori 2000). We focus above all on the interpretation of $P$ - to $S$-wave conversions at the Moho interface (Pms) beneath the stations. We combine the single station measurements into a continuous map of crustal thickness for southern Iberia, and complement the map with previous measurements from Northern Morocco (Mancilla et al. 2012) to produce a complete picture of the Gibraltar arc and surrounding areas. Finally, we build cross-section images of the lithospheric structure by stacking the receiver function amplitudes to follow the seismic discontinuities all across the study region.

Recently, Thurner et al. (2014) published a $P$-wave receiver function study using a similar station distribution in central and western Betics, but with significantly less stations than our analysis in the eastern Betics. They derived a Moho depth map from their CCP images. In our study, we provide as additional information the individual crustal thickness value and the $v_{P} / v_{S}$ ratio for each station, together with error bars and information about the quality of the receiver functions. Our results confirm most of their results in the common areas and provided more details in eastern Betics leading to some important differences in the interpretation.

\subsection{Geological setting and previous analysis}

The study area is divided into two main tectonic units: the Iberian Massif, and the Betic domain. The Iberian massif forms a major part of the Iberian Peninsula and represents one of the best exposed fragments of the European Variscan orogen (Fig. 1). We probe the southern part of the Iberian massif, which was formed by oblique compression between three tectonic blocks: the South Portuguese Zone (SPZ), the Ossa-Morena Zone (OMZ) and the Central Iberian Zone (CIZ) (for a review see Simancas et al. 2005).

The Betic domain is traditionally divided into the External Zones, the Internal Zones (or Alboran domain), and the Flysch units. The External Zones represent the Mesozoic-Paleogene rifted continental margin of Iberia. They contain Mesozoic and Tertiary sedimentary rocks deposited on the Iberian continental paleomargin prior to the formation of the Betics orogene (Prebetic and Subbetic units, Fig. 1). The External Zones were folded and thrusted in a northwesterly direction onto the Iberian foreland in the Miocene. The Alboran domain (or Internal Zone) is composed mainly of Paleozoic and Mesozoic meta-sedimentary rocks with varying metamorphic grade, and Neogene basin deposits (Fig.1; e.g. Lonergan \& White 1997). The Flysch units are allochthonous sedimentary covers deposited in a deep sea trough.

The Gibraltar arc, the Betic orogenic belt and its Moroccon counterpart, the Rif, formed during the Miocene continent-continent collision between Iberia and Africa. During the collision, the Alboran domain thrust westward (e.g. Platt et al. 2003) over the previously thinned Iberian and Maghrebian passive continental margins sweeping Flysch Trough units onto south Iberia and North Morocco (Fig. 1).

This tectonic environment produces widely distributed seismicity. Most of the earthquakes occur at shallow depths [Supporting Information Fig. SM1, e.g. Morales et al. (1997); Buforn et al. (1997)]. However, earthquake of intermediate depth (40-120 km) are also recorded. The intermediate depth earthquakes are located in the Gulf of Cadiz and in a narrow $\sim 100 \mathrm{~km}$-wide strip, dipping progressively from the south of the Iberian Peninsula to northern Morocco at around $4.5^{\circ} \mathrm{W}$ (Supporting Information Fig. SM1). The occurrence of intermediate depth seismicity suggests that there are deep heterogeneities in the upper mantle as confirmed by tomographic studies (e.g. Serrano et al. 1998; Bijwaard \& Spakman 2000; Bezada 2013). A big part of the shallow seismicity is located in southeastern Iberia and northeastern Morocco and it is related with the Trans-Alboran shear zone (Fig. 1, TASZ). The TASZ accommodates most of the strain produced by the collision between Iberia and Africa in the eastern part of the study area (Stich et al. 2006). This shear-zone is interpreted as a transform fault system (e.g. Rutter et al. 2012) and separates the area to the east where convergence between Iberia and Africa plates is the main driving force, from the area where additional stress produces extension in the Alboran sea (Stich et al. 2006).

Recent tomographic images from first arrivals and surface waves using data from a similar stations distribution as we use here show a high-velocity body in the upper mantle (Bezada 2013; Palomeras et al. 2014) similar to the structures found in previous tomographic studies (Blanco \& Spakman 1993; Calvert et al. 2000; Bijwaard \& Spakman 2000). This high-velocity body, possibly corresponding to oceanic lithosphere, has a slab-like structure dipping steeply towards the east. The projection of this structure on the surface has a curvilinear shape covering the western Betics, the Gibraltar arc and the Rif. However, the connection of this 


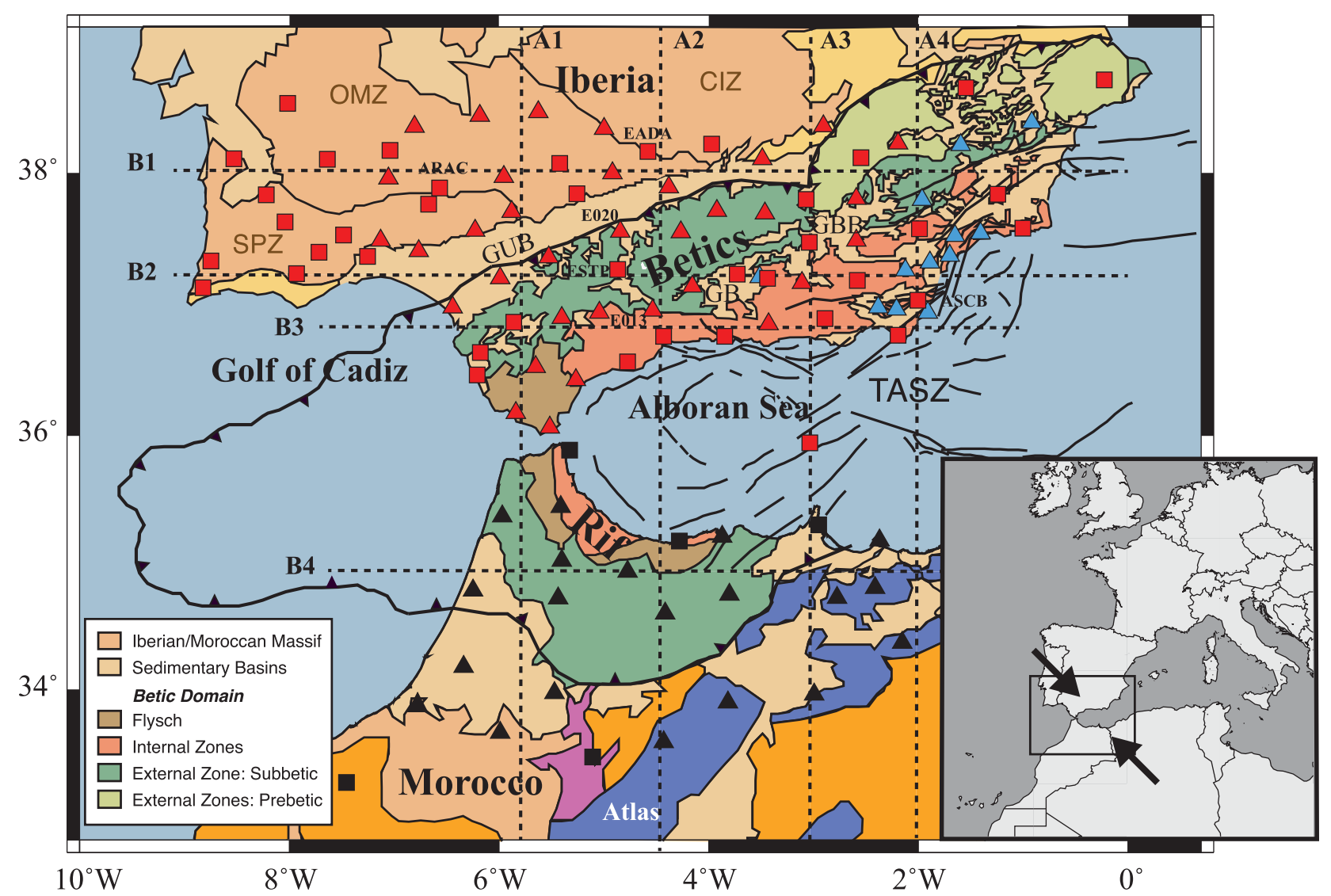

Figure 1. Geological map of the study area with the main tectonic domains. We include the location of the seismic stations analysed in this study (in red and blue) and the stations analysed in previous research whose data have been used in this study (black). We marked the permanent stations with squares and the temporary stations with triangles. The stations displayed with red and black triangles are from the Topolberia experiment and those with blue triangles are from the INDALO experiment. The horizontal and vertical lines mark the cross-sections of the stacked receiver functions (black dotted lines). We include the present-day vector for the relative Nubia-Iberia plate motion in the inset panel and with black lines. (GUB: Guadalquivir Basin; GB: Granada Basin; GBB: Guadix-Baza basin; OMZ:Ossa-Morena Zone; SPZ: South Portuguese Zone; CIZ: Central Iberia Zone; TASZ: Trans-Alboran Shear Zone).

structure with the surface has not been clarified by geophysical studies so far. As we will see our analysis provides new hints about this connection.

Previous characterization of the crustal structure in the south of the Iberian Peninsula has mainly been achieved by active seismic experiments distributed unevenly in the study area (see, Díaz \& Gallart 2009, for a review). They report a crustal thickness of 30$33 \mathrm{~km}$ underneath the Iberian Massif with a flat Moho discontinuity (e.g. Banda et al. 1983; Fernández et al. 2004; Palomeras et al. 2009; Martinez Poyatos et al. 2012). In the Betics domain the crustal thickness values vary sharply from $38 \mathrm{~km}$ beneath the Granada basin down to $22 \mathrm{~km}$ in the east, close to the Mediterranean coast (Banda et al. 1983). Along the contact between the External and Internal Zones from the Granada basin towards the Gibraltar arc crustal thickness of 30-32 km have been reported (Medialdea et al. 1986). Additionally, Julià et al. (2003) performed a $P$-wave receiver function analysis using the same methodology as we use to calculate crustal thickness and $v_{P} / v_{S}$ ratio for 14 stations located in the Iberian Peninsula, four of them in our study area. They obtained similar values for the Iberian Massif, however, they decided not to apply a stacking technique to the stations within the Betics domain, because the method fails due to high complexity of the crustal structure there.

Compared with the crustal structure, the structure of the lithosphere is poorly known. Using the arrival time of the converted phase from $S$-to- $P$ at the Lithosphere-Asthenosphere discontinuity (the LAB discontinuity), Dundar et al. (2011) observed a shallow LAB discontinuity beneath the Iberian massif $(70-80 \mathrm{~km})$, in the Internal zones (Alboran domain) at the southeast of the Iberian Peninsula $(\sim 60 \mathrm{~km})$, the centre of the Alboran sea $(\sim 60 \mathrm{~km})$ and northeast of Morocco $(60-70 \mathrm{~km})$. They found deeper values of $\sim 90-100 \mathrm{~km}$ beneath the Betics and Rif mountain ranges, the south of Portugal and Morocco foreland. Studies from potential fields inversion provide, too, lithospheric thickness estimations (Torné et al. 2000; Fullea et al. 2007, 2010). They reported the same areas with thick lithosphere as the S-RF study but shown strong discrepancies in the values of LAB depths with $\sim 140 \mathrm{~km}$ as their maximum value. However, similar values were obtained in the easternmost part of the Alboran domain $45-70 \mathrm{~km}$.

\section{P-WAVE RECEIVER FUNCTION} A NALYSIS

\subsection{The Data}

We calculated $P$-wave receiver functions (PRF) from teleseismic events recorded at 83 seismic broad-band stations deployed in the south of the Iberian Peninsula (Fig. 1). The data were provided by the TopoIberia consortium (http://iberarray.ictja.csic.es/), which in the study area comprised 34 temporary stations and 38 permanent 
stations. We also included in the analysis data from 11 temporary stations located in the southeast of the Iberian Peninsula (INDALO project, blue triangles in Fig. 1). The relatively dense coverage of seismic stations resulted in an average inter-station distance of $\sim 60 \mathrm{~km}$ for the TopoIberia consortium network and $\sim 30 \mathrm{~km}$ for the INDALO experiment. To complement our analysis, we included the PRF obtained by Mancilla et al. (2013) from 26 stations located in North Morocco (black triangle in Fig. 1).

The data comes from teleseismic earthquakes with magnitudes of 5.5 and higher, over a distance range between $30^{\circ}$ and $90^{\circ}$ to the recording station. The data availability for the permanent stations varies from $9 \mathrm{yr}$ (e.g. CART station) to $1 \mathrm{yr}$ (e.g. EMIN station). In the case of the temporary stations, the minimum recording time is $1 \mathrm{yr}$ and the maximum is $4 \mathrm{yr}$. We obtained altogether 7736 receiver functions from the seismic stations deployed in South Iberia. The number of the PRF for each individual station varies greatly from 18 (E034 station) to 238 (EMAL station) with an average of 95 PRF per station. This variability is mainly due to the differences in the recording time. For the study area, the distance range covers very active seismogenic source areas to the NE (southeastern Asia) and SW (central and south America), while northwestern and southeastern backazimuths are less represented. To show the data coverage and its distribution by backazimuth, in the supplementary material we include a figure with the piercing points of the converted phases at $40 \mathrm{~km}$ depth (Supporting Information Fig. SM1).

\section{$2.2 P$-wave receiver function calculation}

The PRF are time-series containing $P$-to- $S$ converted and multiplyreverberated phases generated at seismic discontinuities beneath the recording station (Vinnik 1977; Langston 1979). In the calculation of the receiver functions, we only used earthquakes with a signal-to-noise ratio greater that 2 . We began by decimating the seismograms to 10 samples per second and filtering them with a Butterworth bandpass filter from $20 \mathrm{~s}$ to $5 \mathrm{~Hz}$. We rotate NEZ coordinate system to RTZ and then rotated the radial and vertical components into the ray coordinate system, thereby obtaining the Q and L components instead of radial and vertical components, respectively (Vinnik 1977). We use the theoretical backazimuth and incident angle computed in the IASP91 Earth model. The PRF are obtained by deconvolving the vertical component from the horizontal components in the time window corresponding to the teleseismic $P$-wave arrival and its coda (Langston 1979). The time windows used are $120 \mathrm{~s}$ long, starting $20 \mathrm{~s}$ before the $P$ arrival. We use an iterative time domain deconvolution method developed by Ligorria \& Ammon (1999), using a Gaussian filter width parameter of 2.5 that translates into receiver function pulses of about $1 \mathrm{~s}$ wide. Ideally, the deconvolution process removes the common signature of the source, the instrument response and the propagation effects before the phase conversion, keeping only the information of the local structure below the seismic station (Langston 1979).

For plane-layered and isotropic media, the transverse component of the PRF is predicted to be zero. Energy on the transverse component is explained by lateral heterogeneity of the medium, in particular by dipping layers, azimuthal anisotropy or scattering (e.g. Cassidy 1992; Savage 1998; Jones \& Phinney 1998). Even though, we observe features in the transverse components that can be explain by dipping layers or anisotropy, in this study we will only focus on the $Q$ receiver functions to obtain crustal thickness values and leave the analysis of the transverse receiver components for a future study.
As an example, Fig. 2(a) shows the PRF for ARAC and EADA stations located in the Iberian massif. The main features observed at these stations are shared by the PRF at most of the stations located in the Iberian Massif. To illustrate this, we present the summation traces for all the stations deployed in the Iberian Massif in Fig. 2(b). In general, the PRF for the stations placed in the Betic domain show greater complexity and variations than those for the stations in the Iberian Massif (Fig. 3). As an example of the PRF in the Betics, we display the PFR for four stations probing the structure of the main units of the Betic domain: near the contact between the Guadalquivir basin and the External Zone (E020 station), the External Zones (ESTP station), the Alboran domain (ASCB station) and near the contact between the External Zones and the Alboran domain (E013 station).

\subsection{Crustal thickness calculation}

To calculate Moho depths, when possible, we used the relative traveltimes for the converted phase, Pms, and its multiples (PpPs, $\mathrm{PpSs}+\mathrm{PsPs}$ ) phases with respect to the direct $\mathrm{P}$ arrival. These relative traveltimes can be utilized to constrain the thickness, $\mathrm{H}$, and the average $v_{P} / v_{S}$ ratio of the crust, provided that the average $P$-wave velocity for the crust is known (Zandt \& Ammon 1995). We apply the receiver function stacking technique (H- $\kappa$ stacking method) developed by Zhu \& Kanamori (2000). In the application of this method, we use grid-steps of $0.1 \mathrm{~km}$ and 0.01 for $\mathrm{H}$ and $v_{P} / v_{S}$, respectively. The parameter search ranges from $15 \mathrm{~km}$ to $55 \mathrm{~km}$ for the crustal thickness and from 1.50 to 2.00 for the $v_{P} / v_{S}$ ratio. The weighting scheme use for the different phases is $w_{1}=0.4$, $w_{2}=0.3$ and $w_{3}=0.3$. The average $v_{P}$ used in the grid search was obtained from previous refraction profiles in the area, $6.3 \mathrm{~km} \mathrm{~s}^{-1}$ for the Alboran domain and the External zones and $6.2 \mathrm{~km} \mathrm{~s}^{-1}$ for the Iberian Massif. (e.g. Banda et al. 1993; Díaz \& Gallart 2009).

To estimate the uncertainties in the crustal thickness and the $v_{P} / v_{S}$ ratio within this grid-search method, we used a bootstrap approach (Efron \& Tibshirani 1991; Julià \& Mejías 2004; Mancilla et al. 2012). We based our statistics on 200 bootstrap replications. For some stations, the stacking surfaces (normalized to 100 per cent) are shown in Fig. 4 along with the $1 \sigma$ confidence ellipses (red) from the bootstrap analysis.

Another source of error comes from plausible deviations from the average $v_{P}$ values (e.g. $0.25 \mathrm{~km} \mathrm{~s}^{-1}$ ) leading to relatively minor bias in depth for typical crustal thickness values $(\sim 1 \mathrm{~km})$ and $v_{P} / v_{S}$ ratio ( $\sim 0.03$ ) (Lombardi et al. 2008). In addition, the vertical resolution of the receiver functions is controlled by the wavelength of the Ps-converted phase, which depends on the spectral content of the recorded signal and the velocity of the medium. Material property gradients occurring over a depth range of a half wavelength can be identified and well characterized (e.g. Sheriff \& Geldart 1982). Average $S$ wavelength is $\sim 3.5 \mathrm{~km}$ in the crust for a $1.0 \mathrm{~s}$ dominant period. In our case, this means that a conservative minimum thickness resolvable for discrete homogeneous layers is $\sim 2 \mathrm{~km}$. Therefore, we take $2 \mathrm{~km}$ as the minimum uncertainty in crustal thickness calculations and 0.03 in the $v_{P} / v_{S}$ ratio. The horizontal resolution is taken as the radius of the first Fresnel zone associated with the incoming $P$-wave (e.g. Sheriff $\&$ Geldart 1982). For a discontinuity at $30 \mathrm{~km}$ depth, the horizontal resolution is $\sim 10 \mathrm{~km}$.

This receiver function stacking method has limitations in the presence of a dipping Moho, a gradient-type crust-mantle boundary instead of a sharp, well-defined Moho discontinuity, or in sedimentary environments (e.g. Julià et al. 2003; Lombardi et al. 2008). For 


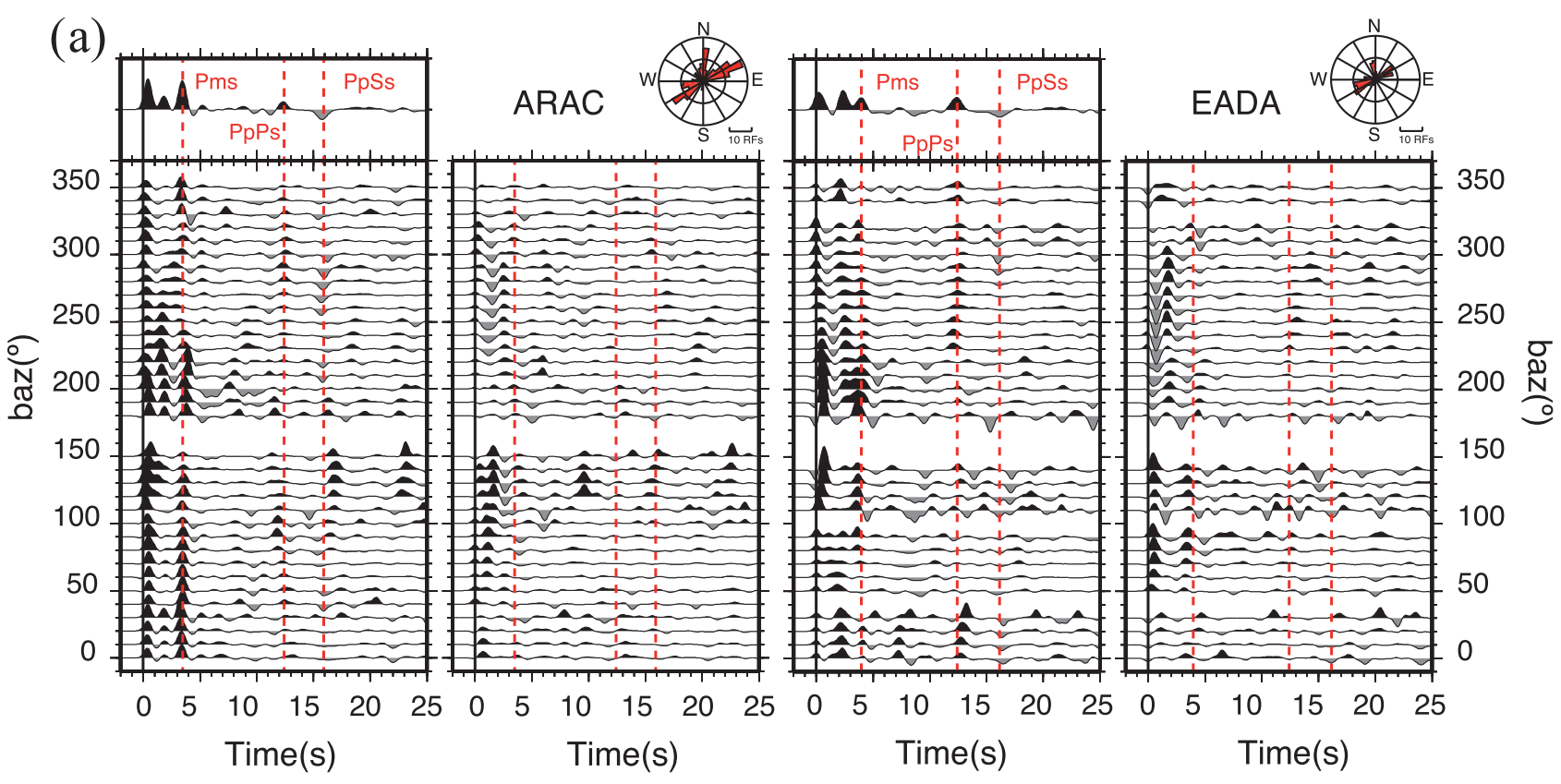

(b)

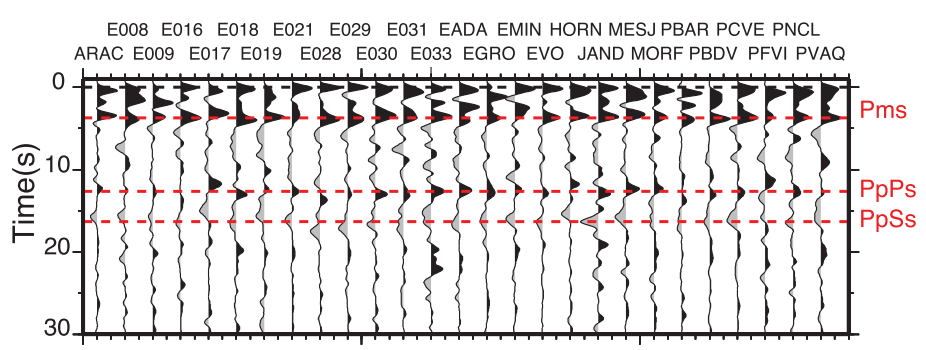

Figure 2. (a) Example of the receiver functions obtained for stations located in the Iberian Massif (see Fig. 1). On the left (right) panels, we plotted the Q component (T components) of the receiver functions stacked by backazimuth in bins of $10^{\circ}$ with an overlap of $5^{\circ}$. The summation trace of the $\mathrm{Q}$ components is displayed on the top. All the traces have been corrected by PpPs moveout prior stacking. The dashed red lines mark the theoretical arrival times for the converted (Pms) and the multiple phases (PpPs and PsPs) at the Moho discontinuity for the crustal thickness and $v_{P} / v_{S}$ ratio obtained in this study (see Table A1).The rose diagrams show the data distribution by backazimuth. (b) Summation traces of the PRF Q components for all the stations located in the Iberian Massif. The arrival times of the Pms phase and its multiples phases for the average crustal thickness $(31 \mathrm{~km})$ and $v_{P} / v_{S}(1.72)$ are marked by dashed red lines.

some stations the above methodology is not applicable, due to a lack of clear multiples or weak Moho conversions. In those cases, the grid-search maxima are poorly constrained or indicate implausible values due to the superposition of unrelated phases.

We classified the stations into three quality categories: in quality $a$ the converted phase and multiples from the Moho discontinuity can be easily recognized from all backazimuth directions; in quality $b$ the converted phase and multiples from the Moho discontinuity are only recognized from some backazimuth directions; and in quality $c$ the multiple phases cannot be distinguished clearly. We obtain reliable results using the stacking method for all the stations in the category $a$ and for some in category $b$.

When the grid-search scheme is not applicable, we estimate the crustal thickness by picking the arrival time of the converted phase, Pms, in the summation trace after applying a Ps-moveout correction to the reference ray parameter of $0.065 \mathrm{~s} \mathrm{~km}^{-1}$. We convert delay time to depth using the average $v_{P} / v_{S}$ ratio from the application of the grid-search stacking method to the rest of the stations belonging to the same domain and the average $v_{P}$ obtained by previous refraction profiles. The uncertainties in these cases for the crustal thickness are constrained by the following modelling.
To illustrate the accuracy of using only the arrival time of the converted phase when dipping layers are present, we performed a test with synthetic receiver functions for a $30 \mathrm{~km}$ dipping crust with an average $v_{P} / v_{S}=1.73$ over a half-space. We use the Frederiksen \& Bostok (2000) code, which allows the inclusion of dipping layers in 1-D Earth models. Our test consisted of a $30 \mathrm{~km}$ thick layer over a half-space with dipping angles of $0^{\circ}, 5^{\circ}, 10^{\circ}, 15^{\circ}$ and $20^{\circ}$. The receiver functions were computed for waveforms approaching the structure from a full range of backazimuths $\left(0^{\circ}-360^{\circ}\right)$ for the reference ray parameter $\left(0.065 \mathrm{~s} \mathrm{~km}^{-1}\right)$, and we also obtained the summation traces. The difference in the arrival time of the converted phase at the Moho discontinuity in the summation traces between a horizontal Moho and a $20^{\circ}$ dipping Moho is $0.2 \mathrm{~s}$, corresponding to an underestimation of $1.6 \mathrm{~km}$ in crustal thickness. Applying to this ideal backazimuth distribution the Zhu \& Kanamori (2000) method results in a crustal thickness of $26.3 \mathrm{~km}$ (underestimation of $3.7 \mathrm{~km}$ ) and a $\mathrm{Vp} / \mathrm{Vs}$ of 1.82 (overestimation of 0.09 ). In general, the application of this Zhu \& Kanamori (2000) method to dipping structure leads to an underestimation of the Moho depth and an overestimation of the $\mathrm{Vp} / \mathrm{Vs}$ ratio (see Lombardi et al. (2008) for a discussion about Zhu \& Kanamori (2000) method and dipping 

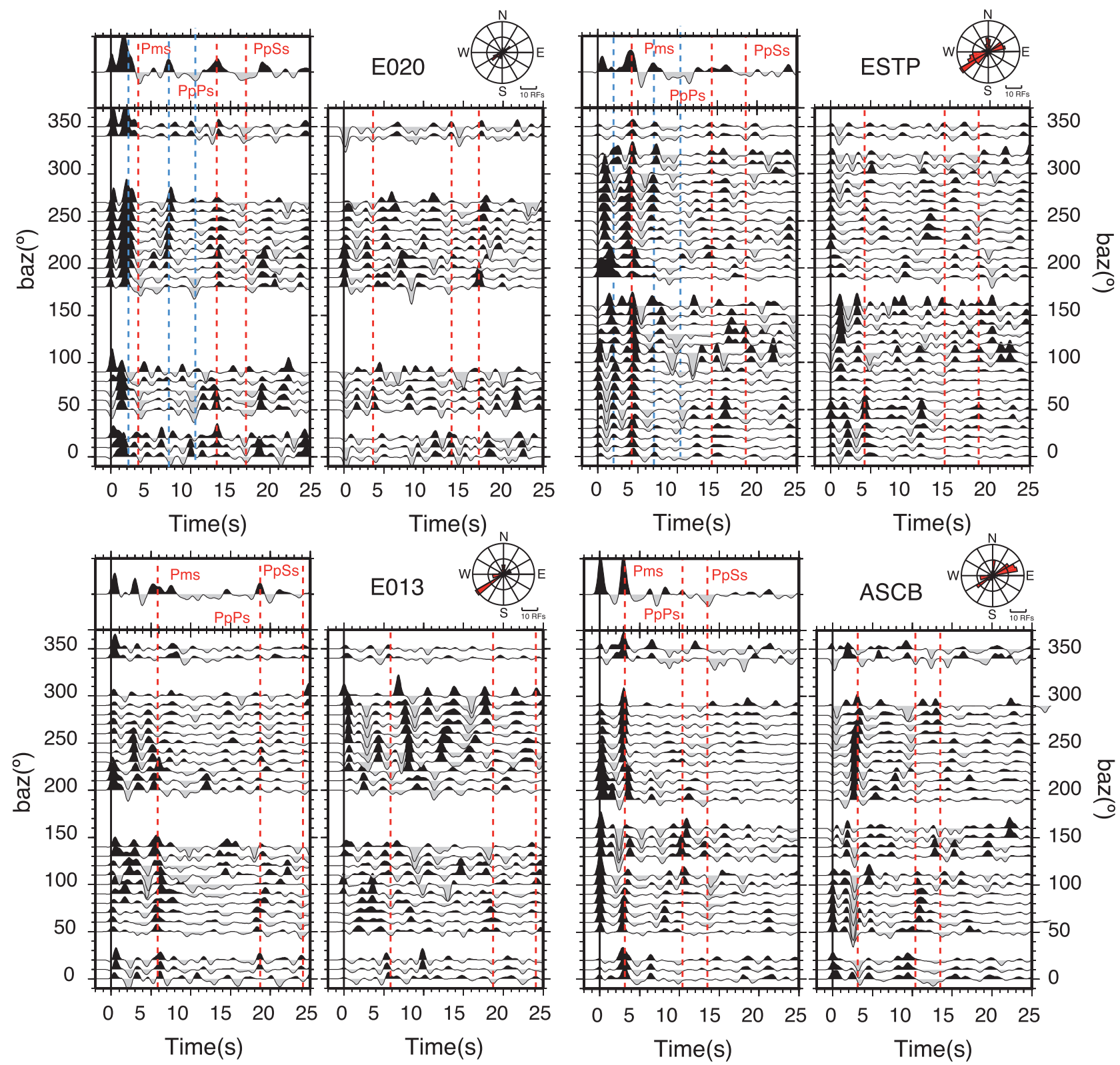

Figure 3. Same as Fig. 2(a) for some stations located in the Betic domain (see Fig. 1). The dashed red lines mark the theoretical arrival times for the converted (Pms) and the multiple phases (PpPs and PsPs) at the Moho discontinuity for the crustal thickness and $v_{P} / v_{S}$ ratio obtained in this study (Table A2). The rose diagrams show the data distribution by backazimuth. The blue dashed line in the plot for E020 and ESTP stations mark the arrival times of the converted and multiple phases at an intracrutal discontinuity.

Moho). Taking a conservative approach, we estimated a minimum error of $2 \mathrm{~km}$ for the quality $a$ and $b$, and an error of $5 \mathrm{~km}$ for quality $c$.

Where the grid search for $\mathrm{H}$ and $v_{P} / v_{S}$ is not applicable and possible ambiguities arise in the choice of the Pms arrival in the receiver functions, we corroborate our decision by building crosssection images with the PRF that allow us to follow the Moho discontinuity between stations. If the converted phase are not clear but the multiples phases are, we use their arrival times to obtain the crustal thickness (as in the case of E020 station).

\subsection{Receiver function cross-section images}

The relatively dense distribution of seismic stations enable us to build images of the upper mantle structure by stacking the am- plitudes of the receiver functions that sample the same volume element. With these images, we try to observe the spatial variation of the lithospheric discontinuities, and in particular to delineate the Moho discontinuity along the different domains and their contacts. The PRF are back-projected (migrated) along the incident ray paths, taking into account the increasing width of the Fresnel zones with depth (e.g. Yuan et al. 2000). A modification of the IASP91 reference velocity model (Kennett \& Engdahl 1991), including the crustal information obtained from previous refraction profiles (see Díaz \& Gallart 2009, for a review), was used to convert delay time to depth. Because the inter-station distance is $\sim 60 \mathrm{~km}$ on average, 3 -D-images of the entire volume are affected by uneven ray path coverage at shallow (crustal) depth. Therefore, the $P$-to- $S$ converted phases are imaged into 2-D spatial cross-sections. In one crosssection, we stack all the PRF amplitudes with piercing points inside 

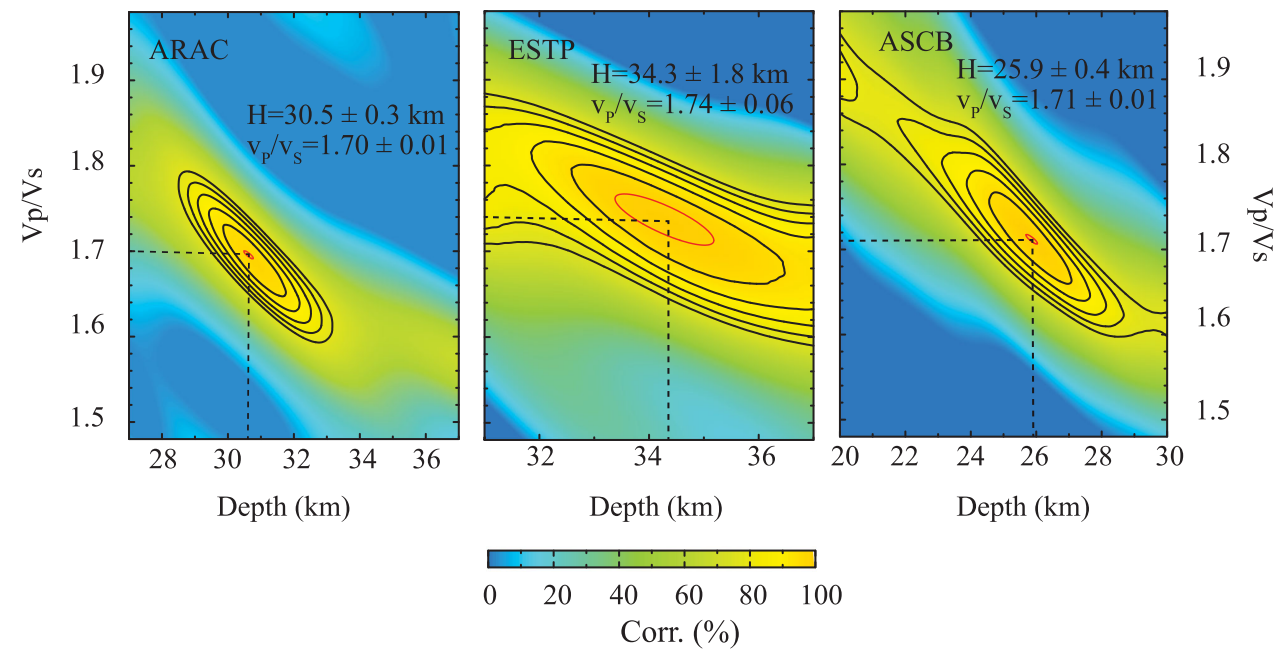

Figure 4. Some examples of the grid search results to obtain the Moho depth and the Vp/Vs. The maximum for the stacking function is marked with dashed lines. The stacking surfaces (normalized to 100 per cent) are shown along with the $1 \sigma$ confidence ellipses from the bootstraps analysis (red ellipse).

a band with a half-width of $40 \mathrm{~km}$ at both sides of the profile. However, in northern Morocco, we use a half-width of $60 \mathrm{~km}$ due to the fact the stations are further apart than in southern Iberian Peninsula. With the stack, we enhance coherent features inside the band and suppress noise. We add the PRF from Northern Morocco obtained by Mancilla et al. (2012) to the ones calculated in this study, using a total of $\sim 11.200$ PRF to build the cross-section images.

\section{RESULTS}

\subsection{Crustal thickness values}

The observed arrival times of the Moho conversion phase in the south of the Iberian Peninsula, Pms, range from 2.3 to $5.6 \mathrm{~s}$, showing great variability even at short distances. These time variations correspond to a factor of $\sim 2.5$ in crustal thickness indicating significant regional and local variations of the crustal structure mainly in the Betic domain. Around half of the stations, 44, show sufficiently clear Moho conversions, and multiples phases to provide well-constrained and unambiguous estimates for crustal thickness (H) and $v_{P} / v_{S}$ ratio through the grid-search approach described in the above section (Fig. 5). The obtained values (noted by $H^{\text {Zhu }}$ and $v_{P} / v_{S}$ Zhu , respectively) are summarized in Tables A1, A2 and A3 included in the Appendix. The results are well constrained for these stations with uncertainties from the bootstrap analysis in the crustal thickness ranging from 0.3 to $2.5 \mathrm{~km}$ and for the $v_{P} / v_{S}$ ratios varying from 0.01 to 0.08 . For some stations the error estimation from the bootstrap analysis is lower than the uncertainties from the frequency content of the receiver functions. The uncertainties in the $v_{P} / v_{S}$ for some stations showed very high values in comparison with the uncertainties in crustal thickness [i.e. a variation of 0.08 is the difference between felsic and ultramafic rocks, see Christensen (1996)]. We took this into account when we perform interpretations derived from the $v_{P} / v_{S}$ ratio. When the solution from the grid-search is not well-constrained we estimate the crustal thickness using the arrival time of the converted phase in the Q component summation trace (noted by $H^{P s}$ in the tables).

We plot in different maps the crustal thickness values obtained by the $H-\kappa$ stacking method (Fig. 5a top panel) and by using the arrival time of the Pms phase (Fig. 5a bottom panel). From this figure we observe that the $H-\kappa$ stacking method fails mainly in the Betics. The maps illustrate the consistency between the results from the two methods.

Twenty-nice of the stations analysed are located in the southern part of the Iberian Massif covering mainly the South Portuguese Zone and the Ossa-Morena Zone (see Fig. 1). For most of these stations, the converted phase at the Moho discontinuity and its multiple phases are clear at most of the backazimuths and easy to identify, with no perceptible variation in their traveltimes with backazimuth (Fig. 2). The $H-\kappa$ stacking method (Zhu \& Kanamori 2000) provides stable results at 24 stations of the Iberian Massif stations (Table A1). The crustal thickness varies from $28.3 \mathrm{~km}$ to $32.3 \mathrm{~km}$ with an average crustal thickness of $\sim 31 \pm 2 \mathrm{~km}$. The $v_{P} / v_{S}$ ratio ranges from 1.68 to 1.77 with an average value of $\sim 1.72 \pm 0.04$. Most of the stations (20 out of 24 ) have values of $v_{P} / v_{S}<1.75$ (Fig. 5b). Our results indicate a very homogenous crustal structure through the south of the Iberian Massif, regardless of the different terranes. Previous studies using PRF in the Iberian massif and passive seismic profiles agree with our values for crustal thickness within the error bars (e.g. Julià \& Mejías 2004; Banda et al. 1983; Fernández et al. 2004; Palomeras et al. 2009; Martinez Poyatos et al. 2012; Thurner et al. 2014).

The PRF for the stations in the Betic domain show more complexity and variability than those in the Iberian Massif. We observed an increase in the arrival time of the converted phase from the stations located on the outer edge of the External zones towards the contact between the External Zones and the Alboran domain, where the highest values are found (Tables A2 and A3). We obtain smaller arrival times and less complexity in the receiver function in the Alboran domain (Fig. 3). Of the 54 stations located in the Betic domain, we get stable results for the $H-\kappa$ stacking method for only 20 stations (Fig. 5). For these stations, we obtain an average $v_{P} / v_{S}$ ratio of $\sim 1.73 \pm 0.05$ for the whole area. Similar values are found in the External zones (Table A2) and the Internal zones (table A 3 ). Most of the obtained $v_{P} / v_{S}$ ratios have values lower that 1.76 , with an average of 1.73 similar to those obtained in the Iberian Massif. The $v_{P} / v_{S}$ ratios indicate a relatively homogeneous average crustal composition (Fig. 5b). The complexity of the crustal structure causes the failure in the application of the grid-search method for the majority of the stations in this domain. 
(a) Crustal Thickness $(\mathrm{km})$
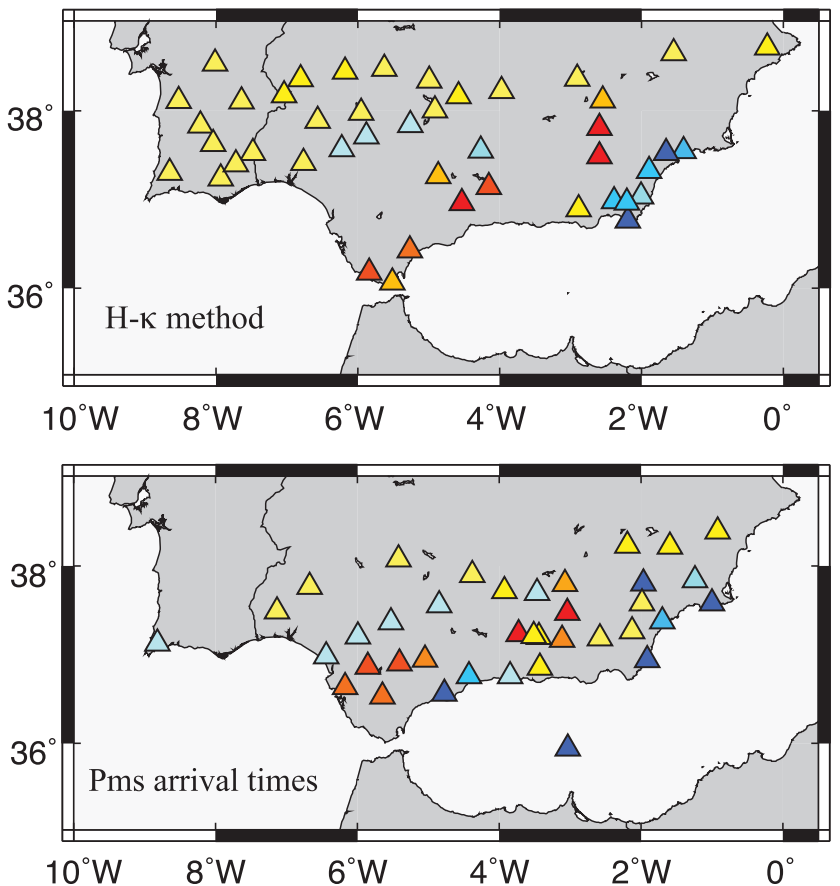

(b) $\mathrm{v}_{\mathrm{P}} / \mathrm{v}_{\mathrm{S}}$ ratio

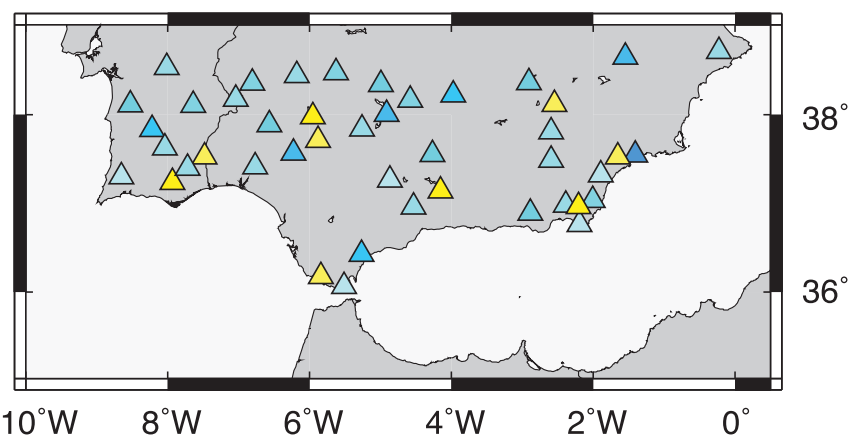

$10^{\circ} \mathrm{W}$

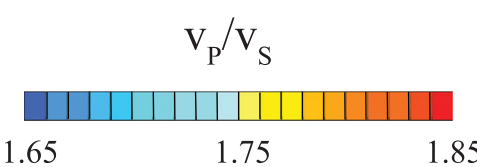

1.65

Crustal Thickness $(\mathrm{km})$

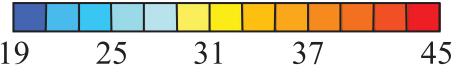

Figure 5. (a) Maps with the crustal thickness values obtained by the H- $\kappa$ method (top panel) and by the Pms arrival times (bottom panel). (b) Map with the $v_{P} / v_{S}$ obtained by the $\mathrm{H}-\kappa$ method. Stations (triangles) are colour-coded according to crustal thickness values and $v_{P} / v_{S}$ ratios.

The crustal thickness in the Betic domain varies from $19 \mathrm{~km}$ to $46.5 \mathrm{~km}$ (Fig. 5). In the northwest of the Betics domain, underneath the Guadalquivir basin, the Iberian crust thins from the $\sim 32 \mathrm{~km}$ underneath de Iberian massif to $\sim 27 \mathrm{~km}$. Further south, in the External Zones, crustal thickness increases, reaching the highest values at the contact between the External Zones and Alboran domain $(\sim 44.5 \mathrm{~km})$. Differently, in the northeast of the study area, from $\sim 3.0^{\circ} \mathrm{W}$ to the east, the crustal thickness increases from the Iberian massif $(\sim 31 \mathrm{~km})$ towards the south, reaching the highest value near the contact between the Prebetic and Subbetic domain of the External Zones $(\sim 46 \mathrm{~km})$. The crustal thickness values inside the Alboran domain are lower than in the External Zone, decreasing towards the Mediterranean coast with a minimum crustal thickness of $\sim 19 \mathrm{~km}$.

Previous crustal thickness values in the Betics domain obtained by active seismic experiments (Díaz \& Gallart 2009) reported systematic lower values in the thicker areas (mainly External zones): for example, $31 \mathrm{~km}$ under the Gibraltar arc ( $\sim 11 \mathrm{~km}$ in this study) and $38 \mathrm{~km}$ under the Granada basin ( $\sim 43-45 \mathrm{~km}$ in this study). The areas with the main discrepancies are the areas with more complex crustal structure. We think that the orientation and the resolution of these active seismic profiles are inadequate to resolve the complexity of the area where sharp variations of crustal thickness can result in significant differences between estimations from both approaches. It is worthy to note that the crustal thicknesses derived from PRF shows more consistency with Bouguer anomaly maps by BGI (Bureau Gravimtrique International http://bgi.obs) than those derived from active seismic experiments. Thurner et al. (2014) with equivalent station distribution built a crustal thickness map derived from the CCP images obtained by PRF. Although no individual crustal thickness values are given, from the colour-code of their figure, its seems that in general the crustal thickness values are a

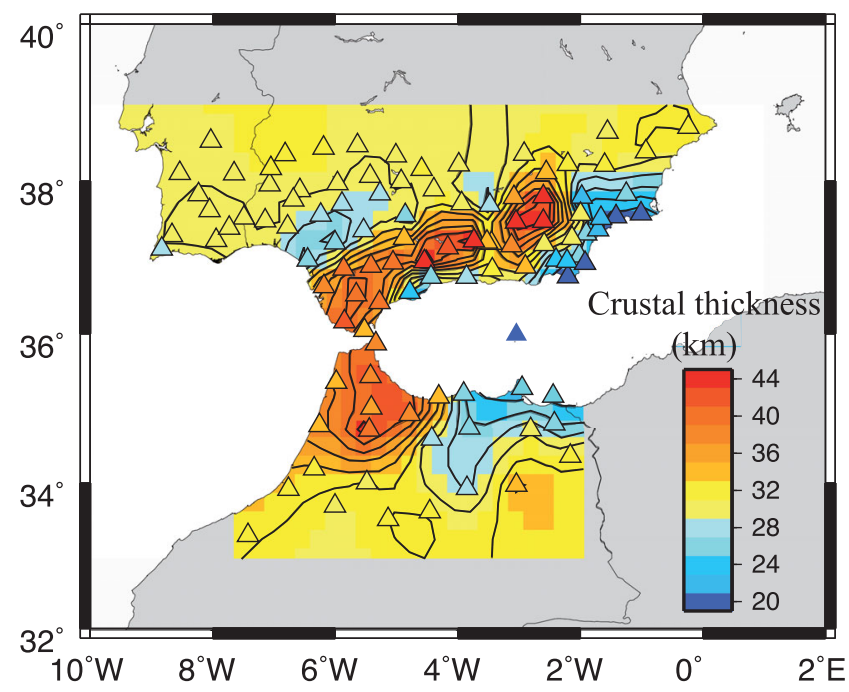

Figure 6. Crustal thickness map of the Gibraltar arc and surrounding areas. Data from southern Spain are obtained in this study and from northern Morocco in Mancilla et al. (2012). Stations (triangles) are colour-coded according to crustal thickness values and interpolated to build crustal thickness surfaces for the whole area.

little bit bigger that our values but inside the error bars and it could be because of the differences in the used velocity model.

To better visualize the results in crustal thickness, we build a map (Fig. 6), using a continuous curvature gridding algorithm [GMT software, Wessel \& Smith (1998)] for interpolation. To reduce oscillation of the interpolation surface outside the station coverage, we fix the crustal thickness along the northern edge at the average value in the Iberian Massif $(31 \mathrm{~km})$. In the map we include the 
$39^{\circ} \mathrm{N}, 5.75^{\circ} \mathrm{W}$

$33^{\circ} \mathrm{N}, 5.75^{\circ} \mathrm{W}$

$39^{\circ} \mathrm{N}, 3^{\circ} \mathrm{W}$

$33^{\circ} \mathrm{N}, 3^{\circ} \mathrm{W}$
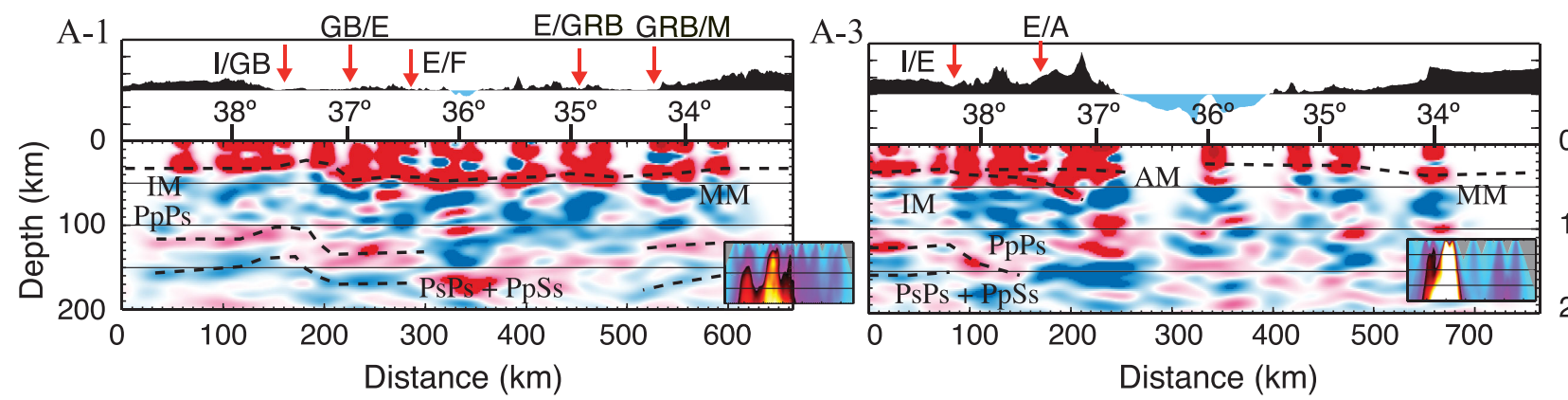

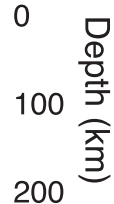
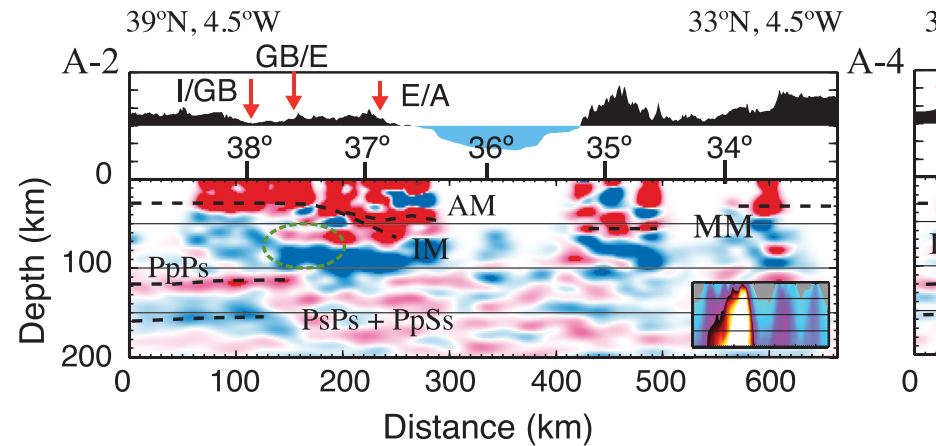

$39^{\circ} \mathrm{N}, 2^{\circ} \mathrm{W}$

$33^{\circ} \mathrm{N}, 2^{\circ} \mathrm{W}$

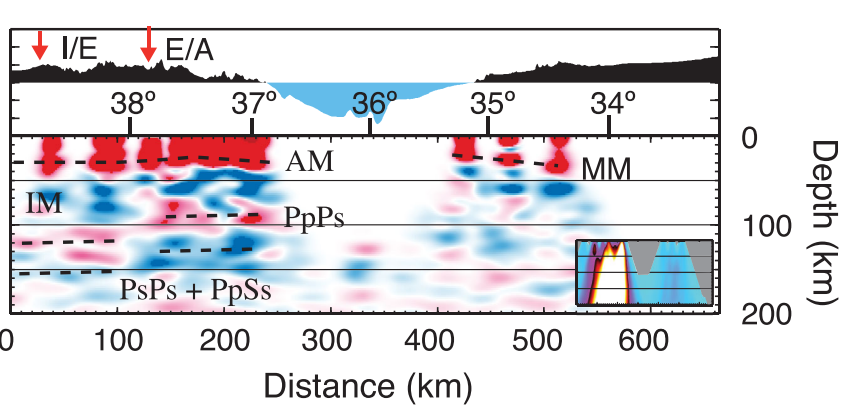

$\mathrm{N}^{\circ}$ of Samples

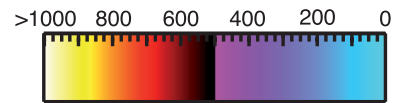

Figure 7. Stacked $P$-receiver function images along four north-south cross-sections at longitudes $5.75^{\circ} \mathrm{W}, 4.5^{\circ} \mathrm{W}, 3^{\circ} \mathrm{W}$ and $2^{\circ} \mathrm{W}$ (named A-1, A-2, A-3 and A-4, respectively). Red indicates positive velocity contrast with depth and blue negative velocity contrast with depth. Dashed black lines mark the conversion depth of the Ps converted phase at the crustal-mantle discontinuity (IM: Iberian Moho, AM: Alboran Moho and MM: Moroccan Moho) and the first reverberated phases (PpPs and PsPs $+\mathrm{PpSs}$ ) generated at this discontinuity. Although not projected to their correct geometrical position at depth, the reverberated phases are useful to confirm the trend of the Moho surface. At the top, we display the topography along the profile where the red arrows mark the contact at the surface of the different tectonic units (I: Iberia foreland, E: External Zones, A: Internal Zones, GB: Guadalquivir Basin, GRB: Gharb basin and M: Moroccan Meseta). In the inset panel, we illustrate coverage, showing the number of samples that contribute to the image at that position. The green dashed line in profile A-2 marks the amplitudes of the multiple phases at an intracrustal discontinuity.

measurements from North Morocco obtained by Mancilla et al. (2012), who reported large crustal thickness values below the Rif domain (crustal thickness 35-44 km), significant crustal thinning (crustal thicknesses 22-30 km) in northeastern Morocco and intermediate crustal thicknesses $(\sim 32 \mathrm{~km})$ in the Moroccan foreland. The combination of both studies gives a complete picture of the variation of the crustal thickness in the Gibraltar arc and surrounding areas.

\subsection{Receiver function cross-section images}

We display stacked PRF along four north-south cross-sections in Fig. 7 (see Fig. 1, named A-1, A-2, A-3 and A-4) and four west-east cross-sections in Fig. 8 (named B-1, B-2, B-3 and B-4). The crosssection A-1 shows the variations of the crustal thickness from the Iberian Massif to the Moroccan Massif through the Gibraltar arc. This cross-section further illustrates the constant crustal thickness beneath the Iberian Massif and Moroccan foreland. From the Iberian massif to the south, the crustal thickness decreases towards the Guadalquivir Basin, as can be seen in the converted phase at the Moho discontinuity and its multiple phases. Following the profile further south from the contact between the Guadalquivir Basin and the External Zones, the crustal thickness starts to increases reaching a thickness of $\sim 41 \mathrm{~km}$ in the Flysch domain. We observe that the
Moho discontinuity is almost flat under the Gibraltar $\operatorname{arc}(\sim 40-$ $41 \mathrm{~km}$ of crustal thickness).

Towards the east (A-2 and A-3 profiles) the Moho discontinuity under the Iberian massif looks as if it continues under the Betics domain as a southward dipping discontinuity into the upper mantle. We associate this upper mantle discontinuity with the Iberian crust that underthrusts the crust of the Alboran domain. Near the Mediterranean coast, the bottom of the Iberian crust reaches $\sim 60-70 \mathrm{~km}$ depth, and is separated from the overlying Alboran crust with thickness of $\sim 25 \mathrm{~km}$. In the cross-section A-2, we mark two strong signals with opposite amplitudes encircling them by a green-dashed line (Fig. 7). We identify these signals as multiples phases from an intracrustal discontinuity at $\sim 19 \mathrm{~km}$ depth observed in few stations as E020 (Ps $\sim 2.2 \mathrm{~s}$ and PpPs $\sim 7.2 \mathrm{~s}$, blue lines in Fig. 3). By contrast, Thurner et al. (2014) interpreted these phases as the converted phase at the top of a detached slab. Further east, cross-section A-4 has different crustal features to the rest of the NS profiles. No crustal thickening is observed beneath the Betics, and the Iberian crust and the Alboran crust can not be differentiated.

The WE cross-section B-1 (at $38^{\circ} \mathrm{N}$, Fig. 8) probes mainly the crust underneath the Iberian massif and the External Zones (Subbetic domain). Again, the Iberian massif exhibits a rather flat Moho through the whole area, as shown by the NS profiles. Towards the east at the contact between the Iberian massif and the External Zones the crustal thickness starts to increase reaching the highest value in 

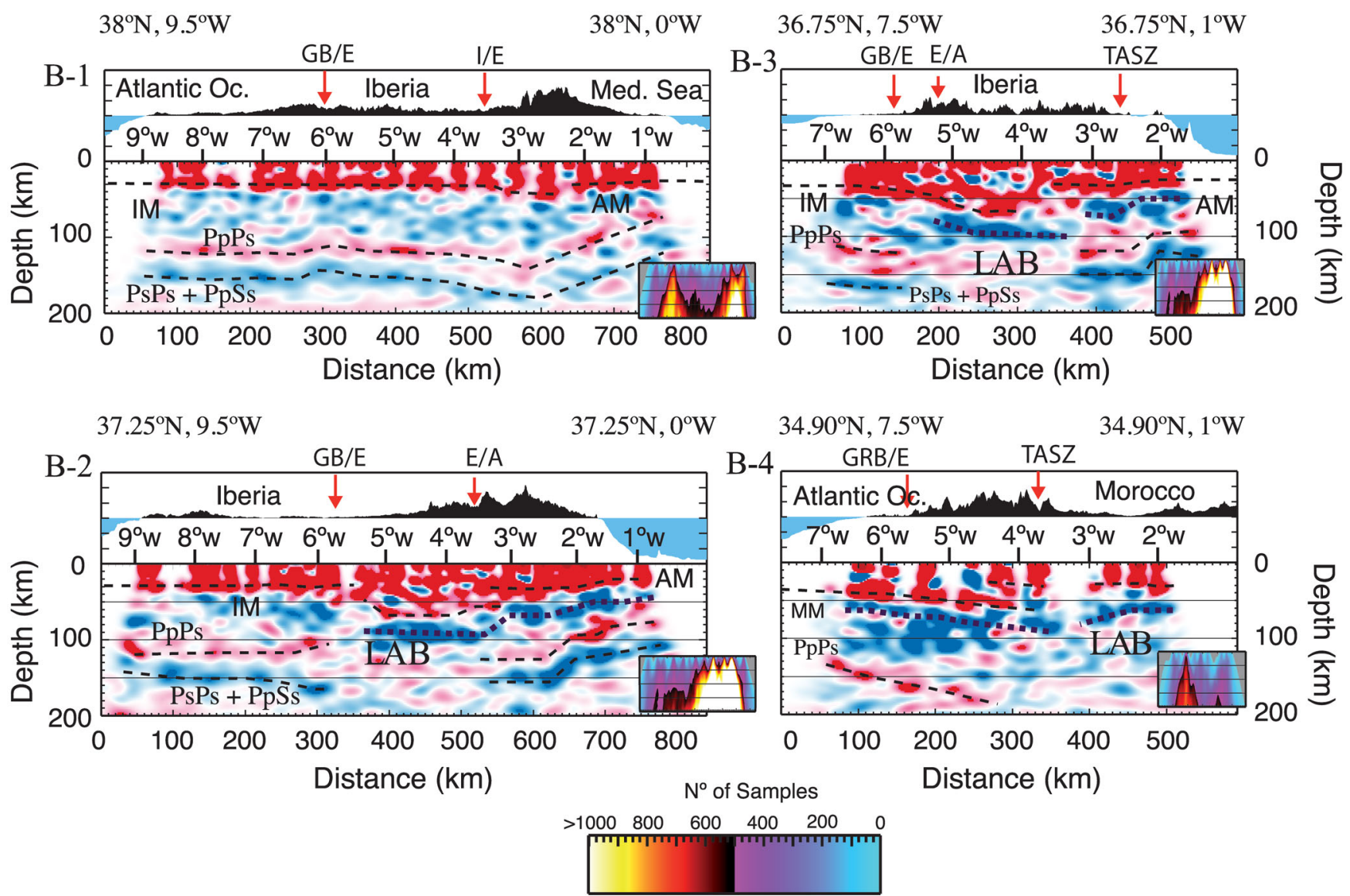

Figure 8. Same as Fig. 7 but for migrated $P$-receiver function images along four west-east cross-sections at latitudes $38^{\circ} \mathrm{N}, 37.25^{\circ} \mathrm{N}, 36.75^{\circ} \mathrm{N}$ and $34.90^{\circ} \mathrm{N}$ (named B-1, B-2, B-3 and B-4, respectively). The top of a low-velocity zone (LAB) is imaged by the migrated receiver functions. We mark the LAB discontinuity in the cross-section with black dotted lines in the areas in which it is most visible. The location at the surface of the TASZ fault system is indicated.

the study area $\sim 46 \mathrm{~km}$ (Fig. 6). This increase in crustal thickness coincides with an increase in topography. To the south, we observe, in cross-section B-2 and B-3, a more complex crustal structure under the External zones. The deepest positive converted phase is produced by a continuous east dipping discontinuity that reaches $\sim 70 \mathrm{~km}$ depth. This discontinuity coincides with the observed underthrusted Iberian crust in the NS profiles (A-2 and A-3). The observation of this discontinuity ends between $\sim 3.5^{\circ}-3.0^{\circ} \mathrm{W}$ under the east edge of the Granada basin. A similar upper mantle discontinuity can be distinguished in the other side of the Gibraltar arc. In northern Morocco, this discontinuity can be followed down to $\sim 50-60 \mathrm{~km}$ depth, ending at $\sim 3.75^{\circ}-3.5^{\circ} \mathrm{W}$.

In the southeast of the Iberia Peninsula, in the area around of the TASZ, the cross-sections B-2 and B-3 reveal a dipping Moho discontinuity with a decrease in the crustal thickness towards the Mediterranean coast. On the other side of the Alboran sea, crosssection B-4 shows that the transition from thick crust in northwestern Morocco to thin crust in northeastern Morocco is sharp and coincides at the surface with the traces of the TASZ fault system (Fig. 1; Mancilla et al. 2012).

A low-velocity layer is clearly observed in some of the crosssections, mainly in the west-east profiles (named LAB in B-2, B-3 and B-4 profiles, Fig. 8). This negative discontinuity is located below the Moho discontinuity and above where the multiples phases appear, and follows the same trend as the Moho discontinuity. We attribute this discontinuity to the lithospheric-asthenospheric bound- ary (LAB). The thickness of the seismic lithosphere underneath the Betic and Rif domains ranges from $\sim 50 \mathrm{~km}$ in areas of thin crust (southeast Iberian peninsula and northeast Morocco) to $\sim 90$ $100 \mathrm{~km}$ below the thickest crust where the foreland crusts underthrust the Alboran crust. The lithospheric thickness has important abrupt lateral variations of $\sim 30 \mathrm{~km}$ under the central Betics and northeast Morocco (B-3 and B-4 profiles) over horizontal distances of $\sim 50 \mathrm{~km}$ or less

In the cross-sections, we detect a duplication of the crust underneath parts of the Betic domain where both domains collided. The highest values of the crustal thickness are reached in areas where the Iberian and Alboran crusts pile up (up to $46.5 \mathrm{~km}$ ). In the areas where the Iberian and the Alboran crust are not in contact, their crusts reach maximum thickness of $\sim 32 \mathrm{~km}$. Where the Iberian crust and the Alboran crust are stacked, the deeper Moho pulse, corresponding to the Iberia crust, defines the crustal thickness in our crustal thickness map (e.g. E013 station). In other areas, the Iberian Moho can be observed as a discontinuity separated from the Alboran crust and entering into the mantle. In those cases, the deeper Moho corresponds to the sinking Iberian crust and the shallower Moho, corresponding to the Alboran crust, defines the crustal thickness in our map (e.g. EMAL station). In some cases, the resolution of the receiver function images and the inter-station distances may prevent us from observing an incipient and small separation between the Iberian and Alboran crusts. 


\section{DISCUSSION}

\subsection{Flat Moho in the south of the Iberian massif}

In this study and in previous works (Banda et al. 1983; Simancas et al. 2003; Martinez Poyatos et al. 2012), the south of the Iberian massif sampled by our study displays a rather flat Moho discontinuity without traces of the crustal root expected below a collisional orogen or major suture boundaries. The crustal thickness values are similar to other parts of the Variscan terranes in Europe (e.g. Tesauro et al. 2008). These values, with an average for the area of $\sim 31 \pm 2 \mathrm{~km}$, are low for a collisional orogen (Artemieva \& Meissner 2012) and insufficient to compensate the topography of $\sim 700$ meters on average.

We obtained an average $v_{P} / v_{S}$ ratio for the crust of the Iberian Massif of $\sim 1.72 \pm 0.03$. This is a medium-to-low value compered with the average continental $v_{P} / v_{S}$ ratio of $\sim 1.76$ (Christensen 1996), corresponding to a felsic-to-intermediate bulk composition (Christensen 1996). Similar values were found in some Archean cratons in which some studies suggest the lack of part of the lower crust (e.g. Durrheim \& Moony 1991; Niu \& James 2002; Thompson et al. 2010). The loss of the orogenic root without any trace of the suture between the different tectonic blocks, suggests that a late-orogenic or post-orogenic event has obliterated the orogenic root and reworked the lower crust (e.g. Simancas et al. 2003; Artemieva \& Meissner 2012; Gutierez-Alonso et al. 2011), as suggested for the Variscan regions of France, Britain and Germany (e.g. Artemieva \& Meissner 2012). This hypothesis also agrees with the observed thin lithosphere $(\sim 70-80 \mathrm{~km})$.

\subsection{Active underthrusting in the Western Betics with the observation of a continental slab}

We find important differences in the lithospheric structure the Betic region west of $\sim 3.5^{\circ} \mathrm{W}$ compare with the east side. To better constrain where the pattern changes, we migrate in a NS profile at $3.5^{\circ} \mathrm{W}$ and $3.0^{\circ} \mathrm{W}$ only the stations closest to the profiles reducing the width of the bins in the direction perpendicular to the profile (Fig. 9). We superimpose the epicentres of the earthquakes located inside a strip of a half degree on both side of the profiles. Below the profiles, we add a sketch of our proposed interpretation.

From North to South, the observed decrease in the crustal thickness underneath the Guadalquivir basin possibly marks the beginning of the transitional crust of the Iberia paleomargin. This thinning was previously observed in a seismic refraction study (Banda et al. 1993) and in a recent PRF study (Thurner et al. 2014). Further south of the Guadalquivir basin, the cross-sections reveal that the Iberian (continental/transitional) crust underthrusts the External zones (Betic domain, formed by sedimentary rocks deposited on the Iberian paleomargin) and the Internal zones. This underthrusted crust develops into a slab-like structure near the coast, and was previously imaged as a low-velocity anomaly by local (e.g. Serrano et al. 1998) and by Rayleigh wave tomography (Palomeras et al. 2014), and coincides with the location of the intermediate-depth seismicity (e.g. Morales et al. 1997). From our observations this continental slab (hereafter referred to as the Iberian slab) shows a continuous connection to the crust under the Iberian Massif. Models of the Guadalquivir basin evolution by Garcia-Castellanos et al. (2002) relate its formation to the loading of the Iberian crust under
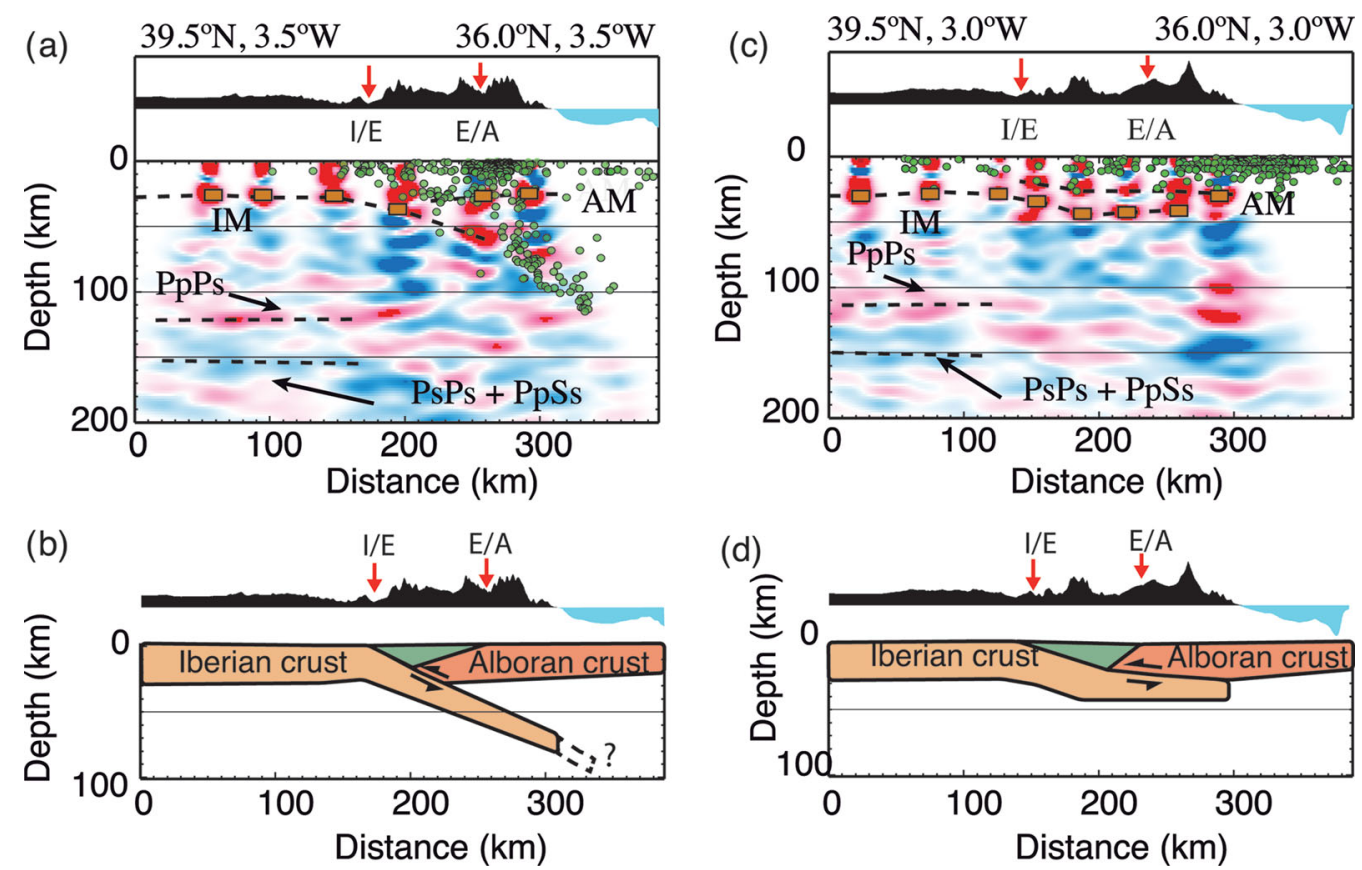

Figure 9. (a) and (d) stacked $P$-receiver function images along NS cross-sections at $3.5^{\circ} \mathrm{W}$ and $3.0^{\circ} \mathrm{W}$, respectively, built using only the closest stations to each profile. Dashed black lines mark the conversion depth of the Ps converted phase at the crustal-Mantle discontinuity (IM: Iberian Moho and AM: Alboran Moho) and the multiples (PpPs and PsPs + PpSs) generated at this discontinuity. The orange squares show the depth of the Moho discontinuity obtained for the station situated above it. At the top, we display the topography along the profile where the red arrows mark the contact at the surface of the different tectonic units; circles represent the hypocentres of earthquakes located along the profile in the longitude range of $4.5^{\circ} \mathrm{W}$ to $3.5^{\circ} \mathrm{W}$, and $3.5^{\circ} \mathrm{W}$ to $2.5^{\circ} \mathrm{W}$, respectively. Earthquake locations are from the International Seismological Centre catalogue (http://www.isc.ac.uk/); (b) and (d) Sketches with our interpretation of the (a) and (d) profiles. 
the External zone with an extra subcrustal load. This extra load could be produced by a pull of the Iberian slab.

This continental Iberian slab seems to be connected to the oceanic slab revealed by regional tomographic studies underneath the Alboran Sea (Blanco \& Spakman 1993; Bijwaard \& Spakman 2000; García-Castellanos \& Villaseñor 2011; Bezada 2013; Palomeras et al. 2014). With our network, we cannot observe the continuation of the Iberian slab offshore. However, its offshore continuation is supported by previous tomographic studies (e.g. Serrano et al. 1998; Palomeras et al. 2014), and the occurrence of the intermediate-depth seismicity (Buforn et al. 1995; Morales et al. 1997).

In contrast with our observation of a continuous connection between the Iberian crust under the Iberian massif and the understrusted Iberian slab from the Granada basin toward the west, Thurner et al. (2014) concluded that there is a gap of the Iberian slab west of the Granada basin. We do not see this gap in our observations (see profiles B2 and B3, Fig 8) and comparing our cross-section images with their CCP images, we think that maybe they misinterpreted some strong multiple phase signals at an intracrustal layer (see green-dashed line in profile A-2, Fig. 8) as the top of a disconnected slab.

Our observation of a continuous slab under the Granada basin and towards the west is supported by the work of Alpert et al. (2013) who show that seismic anisotropy in the western Mediterranean region is best reproduced by mantle flow models that include a continuous, deeply extending slab beneath the Alboran sea which elongates along the Iberian margin from Granada to Gibraltar and curves southward toward the High Atlas. Other models with detached slabs, slabs with spatial gaps, or drip-like features produce results inconsistent with the splitting observations.

The presence of crustal thinning below the Guadalquivir basin may indicate that not the entire transitional crust of the Iberia paleomargin has been consumed in the continental collision in the western Betics. This interpretation is consistent with other geophysical observations of ongoing active shortening at the mountain front in Western Betics. This active shortening is manifested by the concentration of shallow seismicity in the mountain front (Ruiz-Constan et al. 2009; Supporting Information Fig. SM1b) with predominant reverse-faulting mechanisms (Stich et al. 2003, 2006, 2010), and the GPS velocity field measurements (Stich et al. 2006; Mancilla et al. 2013). These observations support a current geodynamic scenario where oceanic subduction has developed into a continental subduction/delamination process in western Betics. There are various other areas in the Mediterranean region where continental subduction/delamination has also been observed, using PRF analysis, including the northern Apennines (e.g. Piana-Agostinetti et al. 2011) and the western Hellenic Subduction Zone (e.g. Pearce et al. 2012).

\subsection{Eastern Betics}

In the Betics east of $\sim 3.0^{\circ} \mathrm{W}$ (profiles B-2 and B-3), we obtain similar crustal thickness values at the northern edge of the External Zones (Pre-betic) as in the Iberian massif ( $~ 31 \mathrm{~km}$; Fig. 6). No thinned crust or transitional Iberian crust is detected near the contact with the External Zones as observed in the western Betics underneath the Guadalquivir basin. Indeed, there is no foreland basin between the Iberian Massif and the External Zones in this area.

We also do not observe a slab structure in this area (Fig. 9). The Alboran crust is lying on top of the Iberian crust and the stacking of both crusts accounts for a total crustal thickness of $\sim 43-$ $46 \mathrm{~km}$ under the External zones. We estimate that the underthrusted Iberian crust is $\sim 20 \mathrm{~km}$ thick. This observation suggests that the transitional crust of the Iberia paleomargin has been completely consumed in Eastern Betics. This is in agreement with the seismicity distribution that it is shallow (Fig. 9c) and concentrate well south of the mountain front, around the northern branch of the TASZ fault system (Fig. 1; e.g. Stich et al. 2006). This seismicity away from the mountain front supports that the underthrusting of the Iberian crust is, at present, inactive in the Eastern Betics. Other geophysical observations that support the change in structure and tectonics from the western to eastern Betics are the GPS velocities (Mancilla et al. 2012). At most of the stations, particularly in the eastern Betics, the measurements indicate small motion $\left(<1 \mathrm{~mm} \mathrm{yr}^{-1}\right)$ relative to stable central Iberia except for a group of eight station located in western Betics.

\subsection{Comparison between the Betic and the Rif domains}

Two WE cross-sections in Fig. 10 show remarkable similarities between Betic domain in southern Iberian peninsula and Rif in northern Morocco. On both sides, we find large crustal thickness near the contact between the External Zones and the Alboran domain adjacent to areas affected by significant crustal thinning. The transition from thick to thin crust is different in both areas, while in the eastern Betics this transition is smooth and continuous, in the Rif it is abrupt with a Moho step of $10-15 \mathrm{~km}$ (Mancilla et al. 2012). In both cases this transition coincides at the surface with the TASZ fault system.

Another point in common is the presence of a subcrustal reflector (Fig. 10). On both sides of the Alboran Sea, these reflectors have an apparent eastward dip and reach depths of 60-70 km near $\sim 3.5^{\circ} \mathrm{W}$ in central Betics and $\sim 50 \mathrm{~km}$ under the east edge of the Rif. These subcrustal reflectors coincide with areas of GPS motion on both sides of the Alboran sea significantly deviates from the current African-Iberian convergence direction (Fadil et al. 2006; Koulali et al. 2011; Mancilla et al. 2013). These anomalies are stronger in Northern Morocco (Fadil et al. 2006; Koulali et al. 2011) and provide evidence for the important role of active subcrustal tectonics in the Iberia-Maghreb plate boundary zone (Fadil et al. 2006; Koulali et al. 2011; Mancilla et al. 2013). An apparent difference between the western Betics and western Rif is their connection to the foreland crust. While crustal thinning is observed underneath the Guadalquivir basin, indicating that the Iberian paleomargin has not yet been completely occupied by the Alboran overthrusting, no crustal thinning has been detected below the Gharb basin south of the Rif (Mancilla et al. 2012).

\subsection{A shallow Lithosphere-Asthenosphere boundary (LAB)}

In general, it is difficult to observe the LAB discontinuity for an average continental lithosphere using PRF. This is because the arrival time of the converted phase at this discontinuity is similar to the arrival times of the multiple phases at the Moho discontinuity. However, when the LAB discontinuity is shallower, it may be detected with the PRF techniques. In the stack cross-sections, we observe the top of a low velocity layer, (mainly profiles B-2 and B-3 Fig. 8). We associate this discontinuity with the Lithosphere Asthenophere boundary (LAB discontinuity). The lithosphere in whole area is thin compared with average continental values 


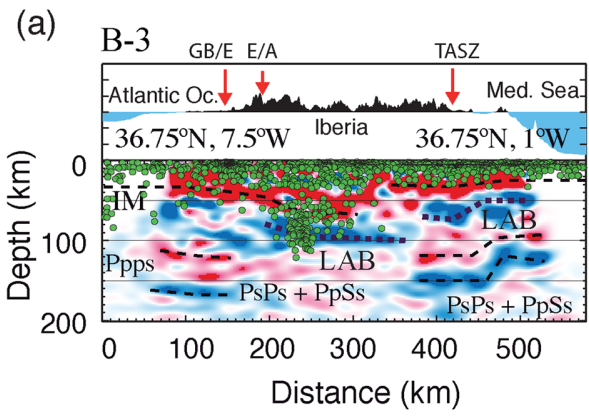

(c)
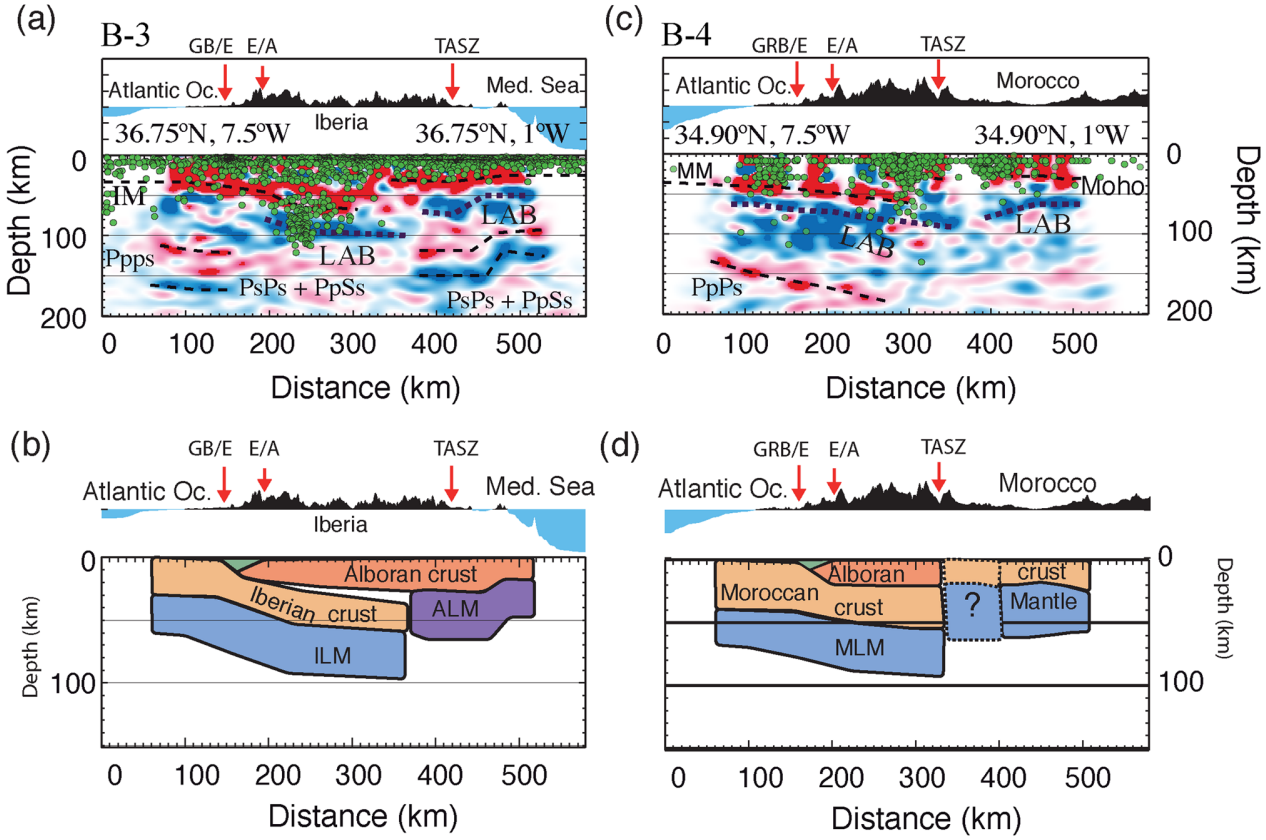

(d)

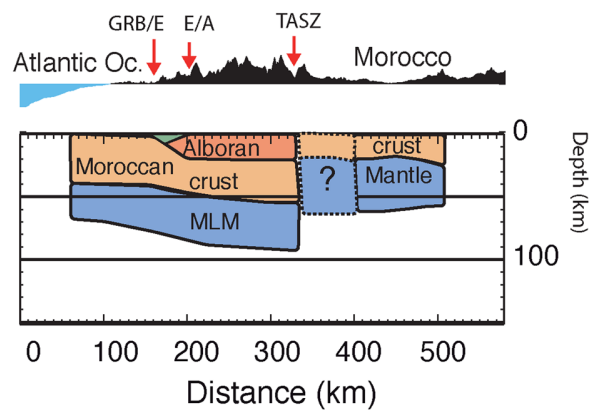

Figure 10. (a) and (c) are B-3 and B-4 profiles, respectively, from Fig. 8, including the hypocentres of earthquakes located along the profiles. Earthquake locations are from the International Seismological Centre catalogue (http://www.isc.ac.uk/); (b) and (d) display sketches with our interpretation of profiles (a) and (c).

(110-150 km). The thickness of the seismic lithosphere ranges from $\sim 50 \mathrm{~km}$ in areas of thin crust to $\sim 90-100 \mathrm{~km}$ below the thickest crust where Iberian and Moroccan foreland crusts underthrust the Alboran crust. The transition from thick to thin under the central Betics and northeast Morocco is abrupt (Fig. 10). In southern Iberia this lithospheric step of $\sim 30 \mathrm{~km}$ occurs over a distance of less than $\sim 50 \mathrm{~km}$ and coincides with the observed change in the crustal structure between the western and the eastern Betics (Fig. 9), and with the highest topography in the area.

Studies on the deep lithospheric structure and LAB depth of the Western Mediterranean region are relatively scarce. Most of them combine geoid gravity, topography, and heat flow data (e.g. Torné et al. 2000; Fullea et al. 2007, 2010). The reported values are consistently larger over the whole area. Observations of conversion phases require sharp discontinuities. Meaning that if we observe the LAB discontinuity using $P$-receiver function it probably is because it represents a boundary in composition, melting, or anisotropy, not temperature alone. Maybe, the differences could arise because both techniques measure different properties of the lithosphere (e.g. thermal versus chemical). Additionally, the strongest differences ( $\sim 60 \mathrm{~km}$ in lithospheric thickness) are in the highest values corresponding to the area where we observed active lithospheric processes. These inversions of potential fields assumed static conditions not taking into account active tectonic processes that contribute to create topography. On the other hand the values provided by Dundar et al. (2011) using $S$-wave receiver functions and by a recent Rayleigh wave tomography (Palomeras et al. 2014) are similar to ours. Rychert \& Shearer (2009) have compiled a global map of the $\mathrm{LAB}$ depth from $\mathrm{P}$ receiver function observations. They found LAB depths of $80-95 \mathrm{~km}$ under active tectonic areas. These studies support our identification of the top of the LVZ with the LAB discontinuity. Palomeras et al. (2014) propose, as other authors before (e.g. Duggen et al. 2005), that this thin lithosphere is a consequence of the removal of the lithospheric mantle at the continental margins beneath Iberia and north Morocco.

\section{SUMMARY AND CONCLUSIONS}

In this study, we obtain thickness and average $v_{P} / v_{S}$ for the crust in the southern part of Iberia, using $P$-receiver functions in an almost regular dense grid of $\sim 60 \times 60 \mathrm{~km}$. We build a crustal thickness map of the Gibraltar arc and the surrounding areas using the values calculated in this study together with the ones obtained by Mancilla et al. (2012). We also delineate the variation of the Moho and LAB discontinuities over the region migrating the $P$-receiver functions to create 2-D cross-section images.

The main findings are:

(i) The Iberian massif has a rather flat Moho discontinuity, an average crustal thickness of $\sim 31 \mathrm{~km}$, and medium-to-low $v_{P} / v_{S}$ ratio of $\sim 1.72$, and a thin lithosphere $(\sim 70-80 \mathrm{~km})$;

(ii) Underneath the Guadalquivir basin, the crust is thinner than in the Iberian Massif and is interpreted as transitional crust of the Iberia paleomargin;

(iii) Southeastern Iberia (the Alboran domain) is affected by significant crustal thinning. The crustal thickness decreases over $\sim 50 \mathrm{~km}$ distance from $\sim 30$ to $\sim 19 \mathrm{~km}$ at the coast.

(iv) The highest crustal thickness values, $\sim 44-46 \mathrm{~km}$, are concentrated along the contact between the External and Internal zones in a NE-SW direction, coincident with the location of Neogene basins and are interpreted to be the result of the underthrusting of the Iberian crust under the Alboran crust;

(v) In western Betics the continental/transitonal underthrusted Iberian crust becomes separated from the Alboran crust and develops into a slab-like structure in the uppermost mantle. A similar slab structure is also imaged beneath northern Morocco. This slab feature is observed continuously from the eastern edge of the Granada Basin, towards the Gibraltar arc until the eastern edge of the Rif domain near the Nekor fault;

(vi) In the eastern Betics, we observe neither a transitional crust, as under the Guadalquivir basin, nor a slab structure. In this area, the Alboran crust is lying on top of the Iberian crust. 
(vii) A thin lithosphere is observed in the whole area, its thickness ranging from $\sim 50 \mathrm{~km}$ in areas of thin crust (southeast Iberian peninsula and northeast Morocco) to $\sim 90-100 \mathrm{~km}$ below the thickest crust where Iberian and Moroccan foreland crusts underthrust the Alboran crust. The transition from thick to thin under the central Betics and northeast Morocco is abrupt, on the order of $\sim 30 \mathrm{~km}$ and occurs over a horizontal distance of $\sim 50 \mathrm{~km}$ or less (Fig. 10).

All these observations support geodynamic scenarios where oceanic subduction has developed into continental subduction/delamination. This process is active in the western Betics where the Iberian continental slab is still connected to the oceanic Alboran slab from the Granada basin, through the Gibraltar arc to the Rif domain. In eastern Betics, this process is inactive and probably the continental/transitional slab broke along a tear fault during the roll-back process of the oceanic Alboran slab. The geodynamic scenarios should also account for a thin lithosphere all over the area.

\section{ACKNOWLEDGEMENTS}

We deeply acknowledge the comments and suggestions made by the editor S. Goes. The reviewers N. Piana Agostti and an anonymous helped to improve the manuscript. We are grateful to the staff of the permanent networks for providing relevant data and to all members of the TopoIberia Seismic Working Group for their hard work in the acquisition and processing of field data. This work is part of the Consolider- Ingenio 2010 project TOPO-IBERIA (CSD200600041). Additional funding was provided by projects CGL200601171, CGL2008-01830, P09-RNM-5100 and CGL2012-31472. We acknowledge work on free software SAC (Goldstein et al. 1999) and GMT (Wessel \& Smith 1998).

\section{REFER EN CES}

Alpert, L.A., Miller, M.S., Becker, T.W. \& Allam, A.A., 2013. Structure beneath the alboran from geodynamic flow models and seismic anisotropy, J. geophys. Res., 118, 4265-4277.

Ammon, C.J., 1991. The isolation of receiver efects from teleseismic $\mathrm{p}$ waveforms, Bull. seism. Soc. Am., 81, 2504-2510.

Artemieva, I.M. \& Meissner, R., 2012. Crustal tickness controlled by plate tectonics: a review of crustal-mantle interaction processes illustrated by European examples, Tectonophysics, 530-531, 18-49.

Banda, E., Udías, A., Mueller, S., Mezcua, J., Boloix, M., Gallard, J. \& Aparicio, A., 1983. Crustal Structure Beneath Spain from Deep Seismic Sounding Experiments, Phys. Earth planet. Inter., 31, 277-280.

Banda, E., Gallart, J., García-Dueñas, V., Doñabeitia, J. \& Makris, J., 1993. Lateral variation of the crust in the Iberian peninsula: new evidence from the Betic Coordillera, Tectonophysics, 221, 53-66.

Bezada2013. Evidence for slab rollback in westernmost Mediterranean from improved upper mantle imaging, Earth planet. Sci. lett., 368, 51-60.

Bijwaard, H. \& Spakman, W., 2000. Non-linear global p-wave tomography by iterated linearized inversion, Geophys. J. Int., 141(71-82).

Blanco, M.J. \& Spakman, W., 1993. The P Velocity Structure of the Mantle below the Iberian Peninsula: Evidence for Subducted Lithosphere below South Spain, Tectonophysics, 221, 13-43.

Buforn, E., Sanz de Galdeano, C. \& Udías, A., 1995. Seismotectonic of the Ibero-Maghrebian Region, Tectonophysics, 248, 247-261.

Buforn, E., Coca, P., Udías, A. \& Lasa, C., 1997. Source mechanism of intermediate and deep earthquakes in southern Spain, J. Seismol., 1, $113-130$.

Calvert, A., Sandvol, E. \& Seber, D., 2000. Geodynamic evolution of the lithosphere and upper mantle beneath the Alboran region of the western Mediterranean: constraints from travel time tomography, J. geophys. Res., 105, $10871-10898$.
Cassidy, J.F., 1992. Numerical experiments in broadband receiver function analysis, Bull. seism. Soc. Am., 82, 1453-1474.

Christensen, N.I., 1996. Poisson's ratio and crustal seismology, J. geophys. Res., 101(B2), 3139-3156.

Díaz, J. \& Gallart, J., 2009. Crustal structure beneath the Iberian Peninsula and surrounding waters: a new compilation of deep seismic sounding results, Phys. Earth planet. Inter., 173(1-2), 181-190.

Duggen, S., Hoernle, K. \& van der Bogaard, H., 2004. Magmatic evolution of the Alboran region: the role of subduction in forming the western Mediterranean and Messian salinity crisis, Earth planet. Sci. Lett., 218, 91-108.

Duggen, S., Hoernle, K., van den Bogaard, P. \& Garbe-Schonberg, D., 2005. Post-collisional transition from subduction- to intraplate-type magmatism in the westernmost Mediterranean: evidence for continental-edge delamination of subcontinental Lithosphere, J. Petrol., 46, 1155-1201.

Dundar, S. et al., 2011. Receiver function images of the base of the lithosphere in the Alboran Sea region, Geophys. J. Int., 187, 1019-1026.

Durrheim, R. \& Moony, W., 1991. Archean and Proterozoic crustal evolution; evidence from crustal seismology, Geology, 19(6), 606-609.

Efron, B. \& Tibshirani, R., 1991. Statistical data analysis in the computer age, Science, 253, 390-395.

Faccenna, C., Piromallo, C., Crespo-Blanc, A., Jolivet, L. \& Rossetti, F., 2004. Lateral slab deformation and the origin of the western Mediterranean arcs, Tectonics, 23, TC1012, doi:10.1029/2002TC001488.

Fadil, A. et al., 2006. Active Tectonics of the western Mediterranean: GPS evidence for roll back of a delaminated sub-continental lithospheric slab beneath the Rif Mountains, Geology, 34, 529-532.

Fernández, M., Márzan, I. \& Tornè, M., 2004. Lithospheric transition from the Variscan Iberian Massif to the Jurassic oceanic crust of the Central Atlantic, Tectonophysics, 386, 97-115.

Frederiksen, A.W. \& Bostok, M.G., 2000. Modelling teleseismic waves in dipping anisotropic structures, Geophys. J. Int, 141, 401-412.

Fullea, J., Fernàndez, M., Zeyen, H. \& Vergés, J., 2007. A rapid method to map the crustal and lithospheric thickness using elevation, geoid anomaly and thermal analysis. Application to the Gibraltar Arc System, Atlas Mountains and adjacent zones, Tectonophysics, 430, 97-117.

Fullea, J., Fernàndez, M., Alonso, J.C., Vergés, J. \& Zeyen, H., 2010. The structure and evolution of the llithosphere-asthenosphere boundary beneath the Atlantic-Mediterranean Transition Region, Lithos, 120, 74-95.

García-Castellanos, D. \& Villaseñor, A., 2011. Messian salinity crisis regulated by competing tectonics and erosion at the Gibraltar Arc, Nature, 480, 359-363.

Garcia-Castellanos, D., Fernández, M. \& Torné, M., 2002. Modeling the evolution of the guadalquivir foreland basin (southern spain), Tectonics, 21(3), 1018, doi:10.1029/2001TC001339.

Goldstein, P., Dodge, D. \& Firpo, M., 1999. International Handbook of Earthquake and Engineering Seismology: Part B, Elsevier.

Gutierez-Alonso, G., Murphy, J.B.J., Fernandez-Suarez, A.B., Weil, M.P.F. \& Gonzalo, J.C., 2011. Lithospheric delamination in the core of pangea: Sm-nd insights from the iberian mantle, Geology, 39(155-158).

Gutscher, M.A., Malod, J., Rehault, J.P., Contrucci, I., Klingelhoefer, F., Mendes-Victor, L. \& Spakman, W., 2002. Evidence for active subduction beneath Gibraltar, Geology, 30, 1071-1074.

Hoernle, K., Zhang, Y.S. \& Graham, D., 1995. Seismic and geochemical evidence for large scale mantle upwelling beneath the eastern Atlantic and western and central Europe, Nature, 374, 34-39.

Jones, C.H. \& Phinney, R.A., 1998. Seismic structure of the lithosphere form teleseismic converted arrivals observed at small arrays in the sourthern Sierra Nevada and vicinity, California, J. geophys. Res, 103(B5), $10065-$ 10090.

Julià, J. \& Mejías, J., 2004. Thickness and Vp/Vs ration Variation in the Iberian Crust, Geophys. J. Int., 156, 59-72.

Julià, J., Ammon, C.J. \& Herrmann, R.B., 2003. Evaluation of deep sediment velocity structure in the New Madrid Seismic Zone, Bull. seism. Soc. Am., 94, 334-340.

Kennett, B. L.N. \& Engdahl, E.R., 1991. Travel times for global earthquake location and phase association, Geophys. J. Int., 105, 429-465. 
Koulali, A. et al., 2011. New GPS constraints on active deformation along the Africa-Iberia plate boundary, Earth planet. Sci. Lett., 308(1-2), 211-217.

Langston, C.A., 1979. Structure under Mount Rainier, Washington, inferred from telesismic body waves, J. geophys. Res., 84, 4749-4762.

Ligorria, J.P. \& Ammon, C.J., 1999. Iterative Deconvolution and Receiver Funcion Estimation, Bull. seism. Soc. Am., 89, 1395-1400.

Lombardi, D., Braunmiller, J., Kissling, E. \& Giardini, D., 2008. Moho depth and Poisson's ratio in the Western-Central Alps from receiver functions, Geophys. J. Int., 173, 249-264.

Lonergan, L. \& White, N., 1997. Origin of the Betic-Rif Mountain, Tectonics, 16(3), 504-522.

Mancilla, F. et al., 2012. Crustal Thickness variations in northern Morocco, $J$, geophys. Res., 117, B02312, doi:10.1029/2011JB008608.

Mancilla, F., Stich, D., Berrocoso, M., Martin, R., Morales, J., FernandezRos, A., Páez, R. \& Pérez-Peña, A., 2013. Delamination in the Betic Range: Deep structure, seismicity and GPS motion, Geology, 41, 307-310.

Martinez Poyatos, D. et al., 2012. Imaging the crustal structure of the Central Iberia Zone (Variscan Belt): the ALCUDIA deep seismic reflection transect, Tectonics, 31, TC3017, doi:10.1029/2011TC002995.

Medialdea, T., Suriñach, E., Begas, R., Banda, E. \& Ansorge, J., 1986. Crustal structure under the western end of the Betic Cordillera (Spain), Ann. Geophys., 4, 457-464.

Morales, J., Serrano, I., Vidal, F. \& Torcal, F., 1997. The Depth of the Earthquake activity in the Central Betics (Southern Spain), Geophys. Res. Lett., 24, 3289-3292.

Morales, J., Serrano, I., Jabaloy, A., Galindo-Zaldivar, J., Zhao, D., Torcal, F., Vidal, F. \& Gonzalez-Lodeiro, F., 1999. Active Continental subduction beneath the Betic Cordillera and Alboran Sea, Geology, 27, 735-738.

Niu, F. \& James, D., 2002. Fine structure of the lowermost crust beneath the Kaapvaal craton and its implications for crustal formation and evolution, Earth planet. Sci. Lett., 200(1-2), 121-130.

Palomeras, I. et al., 2009. Nature of the lithosphere across the Variscan orogen of SW Iberia: dense wide-angle seismic reflection data, J. geophys. Res., 114, B02302, doi:10.1029/2007JB005050.

Palomeras, I., Thurner, S., Levander, A., Liu, K., Villaseñor, A., Carbonell, R. \& Harnafi, M., 2014. Finite-frequency rayleigh wave tomography of the western mediterranean: Mapping its lithospheric structure, Geochem. Geophys. Geosyst., 15(1), 140-160.

Pearce, F.D., Rondenay, S., Sachpazi, M., Chralampakis, M. \& Royden, L.H., 2012. Seismic investigation of the transition from continental to oceanic subduction along the western hellenic subduction zones, J. geophys. Res., 117, B07306, doi:10.1029/2011JB009023.

Piana-Agostinetti, N., Bianchi, I., Amato, A. \& Chiarabba, C., 2011. Fluid migration in continental subduction: the northern apennines case study, Earth planet. Sci. Lett., 302, 267-278.

Platt, J.P. \& Visser, R. L.M., 1989. Extensional collapse of thickened continental lithosphere: A working hypothesis for the Alboran Sea and Gibraltar arc, Geology, 17, 540-543.

Platt, J.P., Allerton, S., Kirker, A., Mandeville, C., Mayfield, A., Platzman, E.S. \& Rimi, A., 2003. The ultimated arc: differential displacement, oroclinal bending, and vertical azis rotation in the external Betic-Rif arc, Tectonics, 22(3), 1017, doi:10.1029/2001TC001321.

Ruiz-Constan, A., Stich, D., Galindo-Zaldívar, J. \& Morales, J., 2009. Is the northwestern Betic Cordillera mountain front active in the context of the convergent Eurasia-Africa plate boundary?, Terra Nova, 21(5), 352-359.

Rutter, A.J., Faulkner, D.R. \& Burgess, R., 2012. Structure and geological history of the Carboneras Fault Zone, SE Spain: part of a stretching transform fault system, J. Struct. Geol., 42, 227-245.

Rychert, C.A. \& Shearer, P.M., 2009. A global view of the lithosphereasthenosphere boundary, Science, 324, 495-498.

Savage, M.K., 1998. Lower crustal anisotropy or dipping boundaries? Effects on receiver functions and a case study in New Zealand, J. geophys. Res, 107(B7), 15 069-15087.

Seber, D., Barazangi, M., Ibenbrahin, A. \& Demnati, A., 1996. Geophysical evidence for lithospheric delamination beneath the Alboran Sea and the Rif-Betic mountains, Nature, 379, 785-790.
Serrano, I., Morales, J., Zhao, D.P., Torcal, F. \& Vidal, F., 1998. P-wave tomographic images in the Central Betics-Alboran sea (South Spain) using local earthquakes: contribution for a continental collision, Geophys. Res. Lett., 25(21), 4031-4034.

Sheriff, R.E. \& Geldart, L.P., 1982. Exploration seismology Volume I: History, Theory and Data Aquisition, Cambridge Univ. Press.

Simancas, F. et al., 2003. Crustal structure of the transpressional Variscan orogen of SW Iberia: SW Iberia deep seismic reflection profile (IBERSEIS), Tectonics, 22(6), 1062.

Simancas, J.F., Tahiri, A., Azor, A., González-Lodeiro, F., Martinez Poyatos, D.J. \& el Hadi, H., 2005. The tectonic frame of the Variscan-Alleghanian orogen in Southern Europe and Northern Africa, Tectonophysics, 398, 181-198.

Stich, D., Ammon, C.J. \& Morales, J., 2003. Moment tensor solutions for small and moderate earthquakes in the Ibero-Maghreb region, J. geophys. Res., 108, doi:10.1029/2002JB002057.

Stich, D., Serpelloni, E., Mancilla, F. \& Morales, J., 2006. Kinematics of the Iberia-Maghreb Plate Contact from Seismic Moment Tensors and GPS Observations, Tectonophysics, 146, 295-317.

Stich, D., Martin, R. \& Morales, J., 2010. Moment tensor inversion for Iberia-Maghreb earthquakes 2005-2008, Tectonophysics, 483(3-4), 390-398.

Tesauro, M., Kaban, M.K. \& Cloetingh, S.A.P.L., 2008. EuCRUST-07: a new reference model for the European crust, Geophys. Res. Lett., 35, L05313, doi:10.1029/2007GL032244.

Thompson, D., Bastow, I.D., Helffrich, G., Kendall, J.-M., Wooky, J., Snyder, D. \& Eaton, D., 2010. Precambrian crustal evolution: Seismic constraints from the Canadian Shield, Earth planet. Sci. Lett., 297, 655-666.

Thurner, S., Palomeras, I., Levander, A., Carbonell, R. \& Lee, C.-T., 2014. Ongoing lithospheric removal in the western Mediterranean: evidence from Ps receiver functions and thermobarometry of Neogene basalts (PICASSO project), Geochem. Geophys. Geosyst., 15, 1113-1127.

Torné, M., Fernández, M., Comas, M.C. \& Soto, J.I., 2000. Lithospheric structure beneath the Alboran basin: results from 3-D gravity modeling and tectonic relevance, J. geophys. Res., 105, 3209-3228.

Vinnik, L.P., 1977. Detection of waves converted from P to SV in the mantle, Phys. Earth planet. Inter., 15, 39-45.

Wessel, P. \& Smith, W.H., 1998. New, improved version of the Generic Mapping Tools released, EOS, Trans. Am. geophys. Un., 79, 579.

Yuan, X. et al., 2000. Subduction and collision processes in the Central Andes constrained by converted seismic phases, Nature, 408, 958-961.

Zandt, G. \& Ammon, C.J., 1995. Continental crust composition constrained by measurement of crustal Poissons ratio, Nature, 374, $152-154$.

Zhu, L. \& Kanamori, H., 2000. Moho depth variation in southern California from teleseismic receiver functions, J. geophys. Res., 105, 2969-2980.

\section{SUPPORTING INFORMATION}

Additional Supporting Information may be found in the online version of this paper:

(http:/gji.oxfordjournals.org/lookup/suppl/doi:10.1093/gji/ggv390 /-/DC1).

Please note: Oxford University Press is not responsible for the content or functionality of any supporting materials supplied by the authors. Any queries (other than missing material) should be directed to the corresponding author for the paper. 


\section{APPENDIX A: CRUSTAL THICKNESS TABLES}

We provide in the following tables the values of crustal thickness and $v_{P} / v_{S}$ ratios obtained by the analysis of the PRF at each station. In table A1, we include the results for the stations located in the Iberian massif; in table A2 for the stations located in the External zones and in table A3 for the station located in the Alboran domain.

Table A1. Estimates for crustal thickness and $v_{P} / v_{S}$ ratio for the stations located in the Iberian Massif. Quality distinguishes (a) clear conversion phase and multiples for all backazimuth, (b) some good backazimuth and (c) no clear multiples. The following columns indicate the total number of receiver functions. $T^{P s}$ is the arrival time of the Pms conversion; $H^{P s}$ denotes crustal thickness for stations where $H-v_{P} / v_{S}$ grid search could not be applied. The right block gives grid search results, $H^{\text {Zhu }}$ and $v_{P} / v_{S}$ Zhu, with their error estimate from bootstrap analysis. Average crustal $v_{P}=6.2 \mathrm{~km} \mathrm{~s}{ }^{-1}$ and $v_{P} / v_{S}=1.71$ to calculate $H^{P S}$.

\begin{tabular}{|c|c|c|c|c|c|c|c|c|}
\hline Station & $\begin{array}{l}\text { Lat } \\
\left({ }^{\circ}\right)\end{array}$ & $\begin{array}{l}\text { Lon } \\
\left({ }^{\circ}\right)\end{array}$ & Quality & N_RF & $\begin{array}{l}T^{P s} \\
(\mathrm{~s})\end{array}$ & $\begin{array}{l}H^{P S} \\
(\mathrm{~km})\end{array}$ & $\begin{array}{l}H^{\text {Zhu }} \\
(\mathrm{km})\end{array}$ & $v_{P} / v_{S}$ Zhu \\
\hline ARAC & 37.8923 & -6.5647 & $\mathrm{a}$ & 112 & 3.5 & & $30.5 \pm 2.0$ & $1.70 \pm 0.03$ \\
\hline E008 & 37.4969 & -7.1304 & $\mathrm{~b}$ & 48 & 3.7 & $30.3 \pm 2.0$ & & \\
\hline E009 & 37.4192 & -6.7651 & $\mathrm{~b}$ & 68 & 3.7 & & $30.0 \pm 2.2$ & $1.72 \pm 0.08$ \\
\hline E016 & 37.9670 & -7.0568 & $\mathrm{~b}$ & 34 & 3.7 & $30.3 \pm 2.0$ & & \\
\hline E017 & 37.5721 & -6.2290 & $\mathrm{a}$ & 67 & 3.3 & & $28.3 \pm 2.0$ & $1.68 \pm 0.03$ \\
\hline E018 & 37.9803 & -5.9548 & $\mathrm{a}$ & 65 & 3.9 & & $30.3 \pm 2.0$ & $1.77 \pm 0.03$ \\
\hline E019 & 37.7161 & -5.8788 & $\mathrm{a}$ & 40 & 3.6 & & $28.6 \pm 2.0$ & $1.75 \pm 0.03$ \\
\hline E021 & 38.0057 & -4.9163 & $\mathrm{a}$ & 49 & 3.5 & & $30.7 \pm 2.0$ & $1.68 \pm 0.06$ \\
\hline E028 & 38.3553 & -6.8073 & $\mathrm{a}$ & 66 & 3.8 & & $32.3 \pm 2.0$ & $1.71 \pm 0.03$ \\
\hline E029 & 38.4397 & -6.1831 & $\mathrm{a}$ & 48 & 3.8 & & $31.1 \pm 2.0$ & $1.73 \pm 0.04$ \\
\hline E030 & 38.4684 & -5.6264 & $\mathrm{a}$ & 55 & 3.5 & & $30.1 \pm 2.0$ & $1.71 \pm 0.03$ \\
\hline E031 & 38.3393 & -4.9967 & $\mathrm{~b}$ & 58 & 3.5 & & $30.1 \pm 2.0$ & $1.70 \pm 0.06$ \\
\hline E033 & 38.3616 & -2.9074 & $\mathrm{~b}$ & 15 & 3.5 & & $30.1 \pm 2.0$ & $1.70 \pm 0.04$ \\
\hline EADA & 38.1673 & -4.5771 & $\mathrm{~b}$ & 100 & 3.9 & & $31.1 \pm 2.0$ & $1.71 \pm 0.04$ \\
\hline ECAB & 38.0753 & -5.4186 & $\mathrm{~b}$ & 54 & 3.6 & $29.5 \pm 2.0$ & & \\
\hline EGRO & 37.5342 & -7.4831 & $\mathrm{a}$ & 127 & 3.7 & & $29.6 \pm 2.0$ & $1.75 \pm 0.04$ \\
\hline EMIN & 37.7675 & -6.6724 & $\mathrm{~b}$ & 159 & 3.6 & $29.5 \pm 2.0$ & & \\
\hline EVO & 38.5294 & -8.0167 & $\mathrm{a}$ & 98 & 3.6 & & $30.4 \pm 2.0$ & $1.72 \pm 0.03$ \\
\hline HORN & 37.8466 & -5.2582 & $\mathrm{a}$ & 117 & 3.4 & & $28.5 \pm 2.0$ & $1.72 \pm 0.03$ \\
\hline JAND & 38.2216 & -3.9705 & $\mathrm{a}$ & 74 & 3.6 & & $30.6 \pm 2.0$ & $1.69 \pm 0.03$ \\
\hline MESJ & 37.8395 & -8.2199 & $\mathrm{a}$ & 83 & 3.5 & & $29.7 \pm 2.0$ & $1.69 \pm 0.03$ \\
\hline MORF & 37.3063 & -8.6508 & $\mathrm{a}$ & 75 & 3.7 & & $29.8 \pm 2.0$ & $1.74 \pm 0.03$ \\
\hline PBAR & 38.1745 & -7.0390 & $\mathrm{~b}$ & 127 & 3.9 & & $32.0 \pm 2.0$ & $1.73 \pm 0.08$ \\
\hline PBDV & 37.243 & -7.9316 & $\mathrm{a}$ & 71 & 3.8 & & $29.9 \pm 2.0$ & $1.76 \pm 0.03$ \\
\hline PCVE & 37.6328 & -8.039 & $\mathrm{a}$ & 67 & 3.6 & & $29.5 \pm 2.0$ & $1.73 \pm 0.04$ \\
\hline PDRG & 38.1079 & -7.6383 & $\mathrm{a}$ & 72 & 3.8 & & $30.7 \pm 2.0$ & $1.71 \pm 0.03$ \\
\hline PNCL & 38.1118 & -8.5290 & $\mathrm{a}$ & 46 & 3.6 & & $30.4 \pm 2.0$ & $1.70 \pm 0.03$ \\
\hline PVAQ & 37.4034 & -7.7173 & $\mathrm{a}$ & 76 & 3.8 & & $29.5 \pm 2.0$ & $1.73 \pm 0.04$ \\
\hline PFVI & 37.1328 & -8.8216 & $\mathrm{~b}$ & 62 & 3.4 & $27.8 \pm 2.0$ & & \\
\hline
\end{tabular}


Table A2. Same as Table A1, for External Zone (PEZ and SEZ), Flysh Units (F) and Guadalquivir basin (GB). Average crustal $v_{P}=6.3 \mathrm{~km} \mathrm{~s}{ }^{-1}$ and $v_{P} / v_{S}=1.73$ to calculate $H^{P S}$

\begin{tabular}{|c|c|c|c|c|c|c|c|c|c|}
\hline Station & $\begin{array}{l}\text { Lat } \\
\left({ }^{\circ}\right)\end{array}$ & $\begin{array}{c}\text { Lon } \\
\left({ }^{\circ}\right)\end{array}$ & Quality & N_RF & $\begin{array}{l}T^{P s} \\
\text { (s) }\end{array}$ & $\begin{array}{c}\sim H^{P s} \\
(\mathrm{~km})\end{array}$ & $\begin{array}{l}H^{\text {Zhu }} \\
(\mathrm{km})\end{array}$ & $v_{P} / v_{S}$ Zhu & \\
\hline E010 & GB & 36.9886 & -6.4431 & $\mathrm{~b}$ & 39 & 3.3 & $27.1 \pm 2.0$ & & \\
\hline E011 & GB & 37.2103 & -5.9905 & $\mathrm{~b}$ & 47 & 3.3 & $27.1 \pm 2.0$ & & \\
\hline E022 & GB & 37.9012 & -4.3818 & $\mathrm{c}$ & 25 & 3.7 & $30.3 \pm 4.0$ & & \\
\hline E034 & SEZ & 38.2299 & -2.1918 & $\mathrm{~b}$ & 18 & 3.9 & $31.8 \pm 2.0$ & & \\
\hline EBEN & SEZ & 38.7038 & -0.2250 & $\mathrm{a}$ & 73 & 3.9 & & $32.5 \pm 2.5$ & $1.73 \pm 0.08$ \\
\hline ETOB & SEZ & 38.6447 & -1.5478 & $\mathrm{a}$ & 55 & 3.4 & & $30.6 \pm 2.0$ & $1.68 \pm 0.04$ \\
\hline SESP & SEZ & 38.1208 & -2.5452 & $\mathrm{~b}$ & 159 & 4.4 & & $34.1 \pm 2.1$ & $1.75 \pm 0.06$ \\
\hline ALJ & PEZ & 36.5299 & -5.6494 & $\mathrm{~b}$ & 66 & 5.1 & $40.5 \pm 2.0$ & & \\
\hline E012 & PEZ & 37.3710 & -5.5249 & $\mathrm{c}$ & 18 & 3.5 & $28.7 \pm 4.0$ & & \\
\hline E020 & PEZ & 37.5653 & -4.8445 & $\mathrm{~b}$ & 47 & 3.4 & $27.8 \pm 2.0$ & & \\
\hline E024 & PEZ & 37.7225 & -3.9241 & $\mathrm{~b}$ & 49 & 4.0 & $32.8 \pm 2.0$ & & \\
\hline E025 & PEZ & 37.7016 & -3.4657 & $\mathrm{c}$ & 88 & 3.3 & $27.1 \pm 4.0$ & & \\
\hline EHUE & PEZ & 37.8135 & -2.5940 & $\mathrm{~b}$ & 83 & 5.5 & & $46.1 \pm 2.2$ & $1.72 \pm 0.06$ \\
\hline ELOJ & PEZ & 37.1464 & -4.1541 & b & 143 & 5.4 & & $42.9 \pm 2.0$ & $1.77 \pm 0.06$ \\
\hline ELUQ & PEZ & 37.5593 & -4.2680 & $\mathrm{a}$ & 124 & 3.0 & & $26.3 \pm 2.0$ & $1.70 \pm 0.03$ \\
\hline EQES & PEZ & 37.8028 & -3.0711 & $\mathrm{~b}$ & 93 & 4.3 & $35.2 \pm 2.0$ & & \\
\hline ESPR & PEZ & 36.8686 & -5.8562 & b & 127 & 5.0 & $41.0 \pm 2.0$ & & \\
\hline ESTP & PEZ & 37.2713 & -4.8662 & $\mathrm{a}$ & 149 & 4.1 & & $34.3 \pm 2.0$ & $1.74 \pm 0.06$ \\
\hline GORA & PEZ & 37.4805 & -3.0398 & $\mathrm{c}$ & 96 & 5.6 & $45.9 \pm 4.0$ & & \\
\hline LIJA & PEZ & 36.9061 & -5.4038 & $\mathrm{~b}$ & 101 & 5.0 & $41.0 \pm 2.0$ & & \\
\hline SELV & PEZ & 37.2383 & -3.7277 & $\mathrm{c}$ & 106 & 5.6 & $45.9 \pm 4.0$ & & \\
\hline SFUC & PEZ & 36.6370 & -6.1750 & $\mathrm{~b}$ & 271 & 4.8 & $39.3 \pm 2.0$ & & \\
\hline ROMA & PEZ & 38.3883 & -0.9182 & $\mathrm{~b}$ & 69 & 4.0 & $32.8 \pm 2.0$ & & \\
\hline XIII & PEZ & 38.2194 & -1.5952 & b & 70 & 3.9 & $32.0 \pm 2.0$ & & \\
\hline E001 & $\mathrm{F}$ & 36.1742 & -5.8392 & $\mathrm{a}$ & 73 & 5.1 & & $41.3 \pm 2.0$ & $1.75 \pm 0.08$ \\
\hline E002 & $\mathrm{F}$ & 36.0610 & -5.5137 & b & 86 & 4.7 & & $34.5 \pm 2.0$ & $1.74 \pm 0.07$ \\
\hline
\end{tabular}

Table A3. Same as Table A1 for Alboran Domain. Average crustal $v_{P}=6.3 \mathrm{~km} \mathrm{~s}^{-1}$ and $v_{P} / v_{S}=1.73$ to calculate $H^{P_{S}}$.

\begin{tabular}{|c|c|c|c|c|c|c|c|c|}
\hline Station & $\begin{array}{l}\text { Lat } \\
\left({ }^{\circ}\right)\end{array}$ & $\begin{array}{l}\text { Lon } \\
\left(^{\circ}\right)\end{array}$ & Quality & N_RF & $\begin{array}{l}\mathrm{T}^{P s} \\
(\mathrm{~s})\end{array}$ & $\begin{array}{c}\sim H^{P s} \\
(\mathrm{~km})\end{array}$ & $\begin{array}{l}H^{\text {Zhu }} \\
(\mathrm{km})\end{array}$ & $v_{P} / v_{S}^{\text {Zhu }}$ \\
\hline ACBG & 36.7687 & -2.1938 & $\mathrm{a}$ & 94 & 2.5 & & $19.8 \pm 2.0$ & $1.74 \pm 0.04$ \\
\hline ACLR & 37.1897 & -2.5822 & $\mathrm{~b}$ & 96 & 3.6 & $30.1 \pm 2.0$ & & \\
\hline ALHA & 36.9878 & -2.3843 & $\mathrm{a}$ & 34 & 3.1 & & $24.9 \pm 2.0$ & $1.72 \pm 0.03$ \\
\hline ANER & 36.7623 & -3.8453 & $\mathrm{~b}$ & 186 & 3.4 & $28.0 \pm 2.0$ & & \\
\hline ASCB & 37.0393 & -2.0057 & $\mathrm{a}$ & 115 & 3.1 & & $25.9 \pm 2.0$ & $1.71 \pm 0.03$ \\
\hline CART & 37.5868 & -1.0012 & $\mathrm{~b}$ & 218 & 2.3 & $19.0 \pm 2.0$ & & \\
\hline CUEV & 37.3290 & -1.8912 & $\mathrm{a}$ & 49 & 3.1 & & $24.9 \pm 2.1$ & $1.74 \pm 0.07$ \\
\hline E005 & 36.4293 & -5.266 & $\mathrm{a}$ & 73 & 4.7 & & $39.2 \pm 2.0$ & $1.69 \pm 0.08$ \\
\hline E006 & 36.9492 & -5.0446 & $\mathrm{~b}$ & 59 & 4.7 & $38.5 \pm 2.0$ & & \\
\hline E007 & 36.8605 & -3.4292 & $\mathrm{~b}$ & 149 & 3.8 & $31.0 \pm 2.0$ & & \\
\hline E013 & 36.9641 & -4.5340 & $\mathrm{a}$ & 87 & 5.5 & & $44.5 \pm 2.0$ & $1.72 \pm 0.05$ \\
\hline E015 & 37.1743 & -3.1115 & $\mathrm{~b}$ & 117 & 4.7 & $38.5 \pm 2.0$ & & \\
\hline E026 & 37.4952 & -2.5945 & $\mathrm{a}$ & 77 & 5.2 & & $43.5 \pm 2.0$ & $1.73 \pm 0.03$ \\
\hline EALB & 35.9399 & -3.0343 & $\mathrm{~b}$ & 84 & 2.4 & $19.0 \pm 2.0$ & & \\
\hline EBER & 36.8979 & -2.8896 & $\mathrm{a}$ & 102 & 3.8 & & $31.7 \pm 2.0$ & $1.70 \pm 0.03$ \\
\hline EMAL & 36.7620 & -4.4292 & $\mathrm{a}$ & 238 & 2.9 & $23.6 \pm 2.0$ & & \\
\hline EMIJ & 36.5645 & -4.7727 & $\mathrm{~b}$ & 200 & 2.1 & $20.3 \pm 2.0$ & & \\
\hline EMUR & 37.8422 & -1.2405 & $\mathrm{~b}$ & 150 & 3.2 & $25.3 \pm 2.0$ & & \\
\hline ENIJ & 36.9713 & -2.2069 & $\mathrm{a}$ & 26 & 3.1 & & $24.5 \pm 2.0$ & $1.77 \pm 0.06$ \\
\hline EQTA & 37.2050 & -3.4399 & $\mathrm{~b}$ & 184 & 4.1 & $32.0 \pm 2.0$ & & \\
\hline GEOD & 37.3828 & -1.7000 & $\mathrm{~b}$ & 66 & 2.8 & $22.4 \pm 2.0$ & & \\
\hline HSAN & 37.2197 & -3.5153 & $\mathrm{a}$ & 80 & 4.0 & $32.0 \pm 2.0$ & & \\
\hline MAZA & 37.5535 & -1.4066 & $\mathrm{a}$ & 58 & 2.5 & & $22.0 \pm 2.0$ & $1.67 \pm 0.05$ \\
\hline MESA & 36.9453 & -1.9109 & $\mathrm{~b}$ & 55 & 2.5 & $20.3 \pm 2.0$ & & \\
\hline MOLI & 37.2720 & -2.1259 & $\mathrm{~b}$ & 65 & 3.6 & $29.4 \pm 2.0$ & & \\
\hline MORA & 37.5308 & -1.6506 & $\mathrm{a}$ & 59 & 2.7 & & $20.8 \pm 2.0$ & $1.75 \pm 0.08$ \\
\hline VALD & 37.8054 & -1.9641 & $\mathrm{~b}$ & 78 & 2.4 & $19.7 \pm 2.0$ & & \\
\hline VELZ & 37.5838 & -1.9880 & $\mathrm{~b}$ & 217 & 3.7 & $30.5 \pm 2.0$ & & \\
\hline
\end{tabular}

